\title{
In Vitro and In Vivo Models for Studying SARS-CoV-2, the Etiological Agent Responsible for COVID-19 Pandemic
}

\author{
Rafael B. Rosa ${ }^{1,2} \mathbb{D}^{\mathbb{D}}$, Willyenne M. Dantas ${ }^{3}{ }^{(D}$, Jessica C. F. do Nascimento ${ }^{1} \mathbb{D}$, Murilo V. da Silva ${ }^{2}$, \\ Ronaldo N. de Oliveira ${ }^{3}$ (D) and Lindomar J. Pena ${ }^{1, *}$ \\ 1 Department of Virology, Aggeu Magalhães Institute (IAM), Oswaldo Cruz Foundation (Fiocruz), \\ Recife 50740-465, Brazil; rafael.rosa@cpqam.fiocruz.br (R.B.R.); jessica.frutuoso7@gmail.com (J.C.F.d.N.) \\ 2 Rodents Animal Facilities Complex, Federal University of Uberlandia, Uberlandia 38400-902, Brazil; \\ murilo.vieira@ufu.br \\ 3 Department of Chemistry, Federal Rural University of Pernambuco (UFRPE), Recife 52171-900, Brazil; \\ willyenne.dantas@ufrpe.br (W.M.D.); ronaldo.noliveira@ufrpe.br (R.N.d.O.) \\ * Correspondence: lindomar.pena@cpqam.fiocruz.br; Tel.: +55-81-2123-7849
}

\section{check for} updates

Citation: Rosa, R.B.; Dantas, W.M.; do Nascimento, J.C.F.; da Silva, M.V.; de Oliveira, R.N.; Pena, L.J. In Vitro and In Vivo Models for Studying SARS-CoV-2, the Etiological Agent Responsible for COVID-19 Pandemic Viruses 2021, 13, 379. https:// doi.org/10.3390/v13030379

Academic Editors: Luciana Barros de Arruda, Fabrício S. Campos and Flavio Guimaraes da Fonseca

Received: 30 November 2020

Accepted: 31 January 2021

Published: 27 February 2021

Publisher's Note: MDPI stays neutral with regard to jurisdictional claims in published maps and institutional affiliations.

Copyright: (c) 2021 by the authors. Licensee MDPI, Basel, Switzerland. This article is an open access article distributed under the terms and conditions of the Creative Commons Attribution (CC BY) license (https:// creativecommons.org/licenses/by/ $4.0 /)$.

\begin{abstract}
The emergence and rapid worldwide spread of severe acute respiratory syndrome coronavirus 2 (SARS-CoV-2) has prompted the scientific community to rapidly develop in vitro and in vivo models that could be applied in COVID-19 research. In vitro models include two-dimensional (2D) cultures of immortalized cell lines or primary cells and three-dimensional (3D) cultures derived from lung, alveoli, bronchi, and other organs. Although cell-based systems are economic and allow strict control of experimental variables, they do not always resemble physiological conditions. Thus, several in vivo models are being developed, including different strains of mice, hamsters, ferrets, dogs, cats, and non-human primates. In this review, we summarize the main models of SARS-CoV-2 infection developed so far and discuss their advantages, drawbacks and main uses.
\end{abstract}

Keywords: SARS-CoV-2; COVID-19; in vivo models; in vitro models

\section{Introduction}

In December 2019, cases of severe pneumonia of unknown origin were reported in Wuhan, China [1]. After phylogenetic analysis, the etiological agent of the severe acute respiratory syndrome was identified as a novel virus member of the Coronaviridae family [2]. The virus was named severe acute respiratory syndrome coronavirus 2 (SARS-CoV-2) by the International Committee on Taxonomy of Viruses (ICTV) [3]. The World Health Organization (WHO) referred the disease caused by the new coronavirus as "COVID-19" in February 2020 [4]. Rapidly, COVID-19 took global proportions and after three months following its emergence, WHO declared it a pandemic [5].

COVID-19 was initially thought of as primarily a respiratory disease, but soon it was recognized that SARS-CoV-2 could affect many body systems, including the respiratory, gastrointestinal, hepatic, ocular, cardiovascular, and neurological [6-8]. Thus, a considerable number of research models have been developed to mimic the disease pathophysiology under experimental conditions.

Several cellular and animal models have been used for studying SARS-CoV-2 infection. In vitro models are useful for studying virus biology under highly controlled conditions, but they often fail to recapitulate the complexity of human body systems $[9,10]$. In vivo models for the SARS-CoV-2 infection together with other methodologies have the potential to elucidate the natural history of the disease, contributing to the discovery of antivirals and vaccines against COVID-19 [11]. However, in vivo studies are costly, require BSL-3 animal facilities, and raise ethical concerns.

In this review, we summarize the in vitro (2D and 3D cell culture) and in vivo models that have been developed for studying SARS-CoV-2 biology and discuss their advantages, drawbacks, and main uses. 


\section{In Vitro Models}

In vitro models are based on two-dimension (2D) or three-dimension (3D) cultures of primary or immortalized cells and tissues. Each methodology has its own applicability and disadvantages for SARS-CoV-2 studies as described in the following sections and summarized in Table 1 . In vitro models comply with the ethical desire for reducing the use of animal models and can answer relevant questions regarding SARS-CoV-2 biology and treatment. They are inexpensive, fast, and allow for the study of specific cellular targets, which could not be assessed in a macroscopic system. However, cell models do not resemble the complexity of a whole organism and translatability of in vitro-generated data to in vivo models can be particularly challenging [12].

\subsection{D-Cell Models: Immortalized Cells}

Monolayer culture of immortalized cells has been used widely for isolating the new coronavirus. The Vero cell line, which is derived from African green monkey kidney, is the most largely used cell line for vaccine production and has been one of the most common cell lines for SARS-CoV-2 isolation around the world. Vero cells are known to express high levels of angiotensin-converting enzyme 2 (ACE2) [13], the cellular receptor used for entry by SARS-CoV-2 [14].

Vero E6 and Huh-7 cells (human hepatocarcinoma) were used to isolate the virus from the first Wuhan patients diagnosed with COVID-19. The presence of cytopathic effect occurred after six days post infection (dpi) [15]. SARS-CoV-2 was also isolated from the first reported South Korean COVID-19 patient using Vero cells. Once again, no cytopathic effect was observed until $5 \mathrm{dpi}$. However, three days after a blind passage, the cytopathic effect characterized by rounding and detachment of cells was seen. Viral particles were visualized by transmission electron microscopy, RNA was sequenced, and the phylogenetic analysis showed the similarity of the strains previously isolated [16]. Harcourt and colleagues isolated the virus from oropharyngeal (OF) and nasopharyngeal (NF) samples in Vero CCL-81 cells and observed the cytopathic effect $2 \mathrm{dpi}$. Virus was detected using real-time quantitative polymerase chain reaction (qRT-PCR) analysis and confirmed by sequencing. Genome sequences of virus cultivated in Vero E6 were also obtained and showed similarity with the parental strain. SARS-CoV-2 grows to similar titers in both Vero-based infection models (CCL-81 and E6), but plaque formation was more visible in Vero E6 cells [17]. Araujo et al. isolated SARS-CoV-2 from the first reported COVID-19 patients in Brazil in Vero-E6 cells and then compared the replication and viral cytopathic effect (CPE) in three Vero cell lines (E6, CCL-81 and hSLAM). The virus grew to similar titers in these cells, but CPE was more pronounced in CCL-81 cells compared to the others. Plaque formation of the Brazilian strain was not clear in Vero E6 cells, but could be seen in Vero CCL81 cells, indicating that different SARS-CoV-2 strains may produce distinct cytopathology in continuous cell lines [18]. SARS-CoV-2 infectivity was studied in human airway epithelium (HAE) and Vero E6. The virus grew to similar titers in both cells, and infection could be blocked by convalescent patient serum. The virus was released apically, not from basolateral side, in HAE cells [19]. Studies with different virus after several passages in Vero cells reported the introduction of adaptive and deleterious mutations in the viral Spike protein that altered SARS-CoV-2 infectivity and its phenotypic characteristics [20,21]. The genetic changes observed during repeated viral passages demonstrate the ability of the virus to adapt quickly to the host. This highlights the need to carefully keep track of viral passage number and in-depth genetic characterization of virus strains prior to perform in vitro and in vivo studies.

Caco-2 cells, a line of colorectal adenocarcinoma, were used for isolating SARS-CoV-2 from infected patients traveling from the city of Wuhan to Frankfurt, Germany [22]. The infection capacity and production of cytokines and chemokines were tested in Caco-2 cells infected with SARS-CoV-1, SARS-CoV-2, MERS-CoV, H1N1pdm, or H5N1 viruses. Caco-2 was susceptible to all tested viruses. SARS-CoV-2 infection in this cell line resulted in low or no pro-inflammatory response [10]. Aiming to establish a permissive cell model 
with Caco-2 cells to detect possible therapeutic targets, Bojkova and colleagues inoculated the previously isolated strain by Hoehl and observed the cytopathic effect within $24 \mathrm{~h}$. Proteomic analysis showed that Caco-2 cells could change their metabolism during viral replication [23].

A549 cells, a human alveolar basal epithelial carcinoma cell line, expressing ACE2 were used to identify host factors required for SARS-CoV-2 replication. Cellular genes were deleted using the clustered regularly interspaced short palindromic repeats (CRISPR) technique and then cells were checked for infection. This methodology allowed assessing the impact of each protein-coding gene in the human genome on viral replication and may pave the way to in vivo pathogenesis studies and to discover countermeasures [24].

Immortalized cells cultured in monolayers have been essential for detecting potential anti-SARS-CoV-2 drugs. Given the SARS-CoV-2 replicative efficiency in Vero E6 cells, they were used for testing drugs and antivirals listed in TargetMol library. After screening, three candidates reduced CPE when compared to untreated cells within $48 \mathrm{~h}$. Cepharanthine was highlighted, since this drug previously showed an inhibitory effect on other coronaviruses (SARS-CoV and HCoV-OC43). After a time-of-addition experiment, the authors proposed that cepharanthine acted since the virus entry until post-viral infection [25]. Using Vero E6 cells as well, the compounds Boceprevir, GC-376 and calpain II/XII inhibitor were tested for SARS-CoV-2 inhibition through evaluation of the cytopathic effect and determination of $\mathrm{EC}_{50}$ in concentrations ranging from 0.49 to $3.37 \mu \mathrm{M}$. The proposed mechanism of action of these drugs was protease inhibition [26]. The compound 6-thioguanine (6-TG), a potent cytotoxic agent used in the treatment of acute leukemia, was tested to inhibit SARS-CoV-2 due to viral papain-like protease inhibition in Vero E6 and Calu-3 cells. Up to concentrations of $50 \mu \mathrm{M}$, the compound showed no cytotoxicity for both cells. The drug was able to inhibit virus replication with $\mathrm{EC}_{50}$ of $0.647 \pm 0.374 \mu \mathrm{M}$ for Vero and $\mathrm{EC}_{50}$ of $0.061 \pm 0.049 \mu \mathrm{M}$ for Calu-3 [27].

Remdesivir (RDV), a nucleoside analog initially planned for the treatment against Ebola and Marburg viruses, was another drug tested for anti-SARS-CoV-2 activity in 2D models. Prior to antiviral analysis, authors verified the reproduction of SARS-CoV-2 in Vero CCL-81, Vero E6, Huh-7 and Calu-3 2B4. Huh-7 showed low permissiveness to SARSCoV-2 in comparison to the other cell lines. Only Vero E6 and Calu-3 cells were used in the antiviral tests with the RDV and GS-441524 (RDV prodrug). In Vero E6 cells, RDV $\left(\mathrm{EC}_{50}=1.65 \mu \mathrm{M}\right)$ proved to be less potent than GS-441524 $\left(\mathrm{EC}_{50}=0.47 \mu \mathrm{M}\right)$ and in Calu-3 cells the opposite was observed (RDV EC $\mathrm{EC}_{50}=0.28 \mu \mathrm{M}$; GS-441524 $\mathrm{EC}_{50}=0.62 \mu \mathrm{M}$ ) [28]. Other FDA-approved drugs have been tested against SARS-CoV-2 in Vero cells, including chloroquine/hydroxychloroquine and ivermectin. Both drugs reduced SARS-CoV-2 replication in Vero cells $[29,30]$. This effect was observed for chloroquine and hydroxychloroquine when administered pre and post-infection and the latter was found to be more potent than the former [30]. Ivermectin treatment of infected Vero cells can cause a 5000-fold reduction in virus RNA levels [29]. However, some points need to be taken into consideration regarding the use of these drugs and their respective studies. These limitations include ivermectin's low water solubility, lack of comparative standard drugs in antiviral tests, absent evaluation of treatment efficacy according to disease severity, and the possible combination with other drugs to maximize antiviral efficacy. Dose adjustment and evaluation of other administration routes are also important points that need to be further assessed. Several clinical trials have been concluded and others are ongoing and the clinical benefits of using these compounds in COVID-19 patients remains uncertain $[31,32]$.

\subsection{D-Cell Models: Explants and Organoids}

The use of primary cells from human airway epithelium (HAE) for isolation and cultivation of other coronaviruses has already been described in previous studies [33]. HAE cells are isolated from human lung donors or individuals undergoing lung transplantation and resemble the human bronchial environment, one of the targets for SARS-CoV-2 infection. Upon isolation, these cells are cultured and differentiated on porous supports at an 
air-liquid interface (ALI), in which the apical side is in contact with air. HAE cells represent a complex tissue with differentiated ciliated, goblet and basal cells and retain the highest similarity to human airway epithelium physiological conditions found in vivo [34,35].

HAE cells were used to isolate and discover SARS-CoV-2 for the first time upon its emergence in Wuhan, China. Bronchoalveolar lavage fluids from three patients with pneumonia of unknown cause were inoculated in a primary culture of lung epithelial cells expanded in an ALI system at $37^{\circ} \mathrm{C}$ and $5 \%$ carbon dioxide $\left(\mathrm{CO}_{2}\right)$. The presence of the virus was visualized by transmission electron microscopy and confirmed by RT-PCR targeting a region of the viral RNA-dependent RNA-polymerase (RdRp) gene of pan $\beta$-CoV. Infected HAE showed cytopathic effects $96 \mathrm{~h}$ after inoculation, which was characterized by a lack of ciliary movement [15].

The ex vivo replication and tropism of SARS-CoV-2 has been studied in HAE cells. Hou and colleagues used HAE obtained from different zones of the respiratory tract (nasal, bronchial, bronchiolar, and alveolar tissue) and air absorption capacity to evaluate the infection with a SARS-CoV-2 reporter virus. Following the expression analysis of the angiotensin II receptor (ACE2) and the viral titers obtained from each cell, HAE from proximal airway (nasal cavity and large bronchi and alveoli) were found to be more susceptible to infection than distal regions. Nasal submucosal glands, type I and II pneumocytes, microvascular endothelial cells, fibroblasts and UNCNN2TS immortalized nasal cells were also tested but showed low viral titers or no infection signs [36].

Stem cells were induced to produce type 2 alveolar epithelial cells (iAT2) in an ALI system aiming to identify gene responses to SARS-CoV-2 infection. Since ACE2 and TMRPSS2 are required for SARS-CoV-2 infection in human cells [37], their gene expression profile was measured in different induced lung cell types. ACE2 and TMPRPSS2 expression was identified in differentiated basal, secretory and ciliated cells, suggesting that they are susceptible to the virus [38,39].

Because the most severe forms and mortality of COVID-19 are seen more often in men than women, the effects of estrogen on the replication of SARS-CoV-2 have been studied under controlled conditions in normal human bronchial epithelial cells (NHBE). According to a recent the study, estrogen reduces the expression of ACE2 and this could modulate the severity of COVID-19 in women [40]. NHBE cells were also used for identifying the expression of several genes in response to SARS-CoV-2 infection, showing an induction of chemokines, cytokines, and interleukins, with limited IFN-I and III responses [41].

Primary cells have also been used in SARS-CoV-2 antiviral research. The broadspectrum oral antiviral $\beta$-D-N4-hydroxycytidine (NHC) was tested on infected human tracheobronchial epithelial cells cultured in an ALI system for 6 to 8 weeks. NHC decreased up to 3 logs the viral replication in concentrations between 0.1 and $10 \mu \mathrm{M}$ without cytotoxic effects, which indicates its potential utility as an antiviral for treating SARS-CoV-2 infection [42]. Camostat and Nefamostat, both protease inhibitors, were tested on human nasal epithelial cells (HNE) infected with SARS-CoV-2, in concentrations between 0.001 and $1 \mathrm{~g} / \mathrm{mL}$, and a decrease in viral replication was achieved. RDV has also been tested on SARS-CoV-2 infected primary cells. Among the tests that have been carried out with this compound, lung epithelial cells cultured in an ALI system were used and showed good antiviral results with cytotoxic concentrations up to $10 \mu \mathrm{M}$. The percentage of viral inhibition reached $100 \%$ at the highest concentrations used and $\mathrm{EC}_{50}$ ranged between 0.001 and $0.009 \mu \mathrm{M}$ [28].

Cellular models based on HAE offer similarity to physiological conditions and maintain many of the important markers and functions from the donor tissue [35]. Despite the great advantages of using primary cells, mainly regarding more realistic virus-host interactions, models based on immortalized cell monolayers are easy to use, less time-consuming and bypass ethical concerns associated with the use of animal and human tissue [34].

The use of 3D-cell models in SARS-CoV-2 research has gained attention due to their similarity with the host organism. Organ-derived explants (ex vivo models) or organoids produced by induced stem cells are beginning to be widely applied in the study of respira- 
tory viral infections [43]. Results obtained from tissues are important for mapping their possible response to viral infection and finding new therapeutic targets. Patient-derived explants have the advantage of preserving overall tissue architecture and complexity when compared to organoids, but the latter can be more easily standardized compared to the former.

COVID-19 patients present symptoms in several systems, including the respiratory, gastrointestinal, hepatic, ocular, and cardiovascular [6,7]. Investigation of possible SARSCoV-2 permissive cells in 13 human tissues was performed through the evaluation of ACE2 expression. Pulmonary AT2 cells, liver cholangiocytes, colonocytes, esophageal keratinocytes, ileum and rectum endothelial cells, stomach epithelial cells and renal proximal tubules presented the highest ACE2 levels, indicating that these cells could be susceptible to SARS-CoV-2 and be used in infection models [44]. With the same goal, Singh and colleagues used scRNA-seq to map different cell types and tissues permissive to the virus. Gastrointestinal and respiratory tract tissues were permissive to SARS-CoV-2, as well as spermatogonia and cells from the placenta [45]. The replicative potential of SARS-CoV-2 has been tested in lung, bronchial and connective tissues obtained from donor patients who underwent surgery. The virus was inoculated at a concentration of $5 \times 10^{5} \mathrm{TCID}_{50} / \mathrm{mL}$ at $37{ }^{\circ} \mathrm{C}$ (lung and bronchi) or $33^{\circ} \mathrm{C}$ (conjunctive tissue) for $1 \mathrm{~h}$. Samples were collected after $1,24,48,72$, and $96 \mathrm{~h}$ and viral load was measured by titration. All tissues proved to be permissive to infection with an increase of viral titers up to 2 logs [10]. Chu and colleagues analyzed SARS-CoV and SARS-CoV-2 infection in lung tissues donated by patients who underwent surgical procedures. SARS-CoV-2 was more infectious when compared to SARS-CoV. In the same study, immune and pro-inflammatory responses were also evaluated. SARS-CoV infection led to increased lung gene expression of IFN I, II, and III and 11 of 13 cytokines/chemokines tested. SARS-CoV-2 infection, on the other hand, did not alter the expression of IFN and induced the expression of only 5 cytokines/chemokines analyzed [46].

Given the hepatic impairment in patients with COVID-19, the permissiveness to SARSCoV-2 infection was evaluated in hepatocyte and cholangiocyte organoids derived from human pluripotent stem cells (iPSCs). Both organoids supported productive SARS-CoV-2 replication and had similar chemokine responses as COVID-19 tissues from autopsy cases [47].

HPSCs-derived lung and colon organoids (hPSCs-LO and hPSCs-CO, respectively) were developed and used for evaluating the anti-SARS-CoV-2 activity of imatinib, mycophenolic acid (MPA) and quinacrine dihydrochloride (QNHC). Both organoids were permissive for SARS-CoV-2 infection. Similar to what is seen in COVID-19 patients, infected hPSC-LOs (particularly alveolar type-II-like cells) revealed upregulation of cytokines and chemokines [48].

Severe cases of COVID-19 can display neurological complications that are manifested by headache, confusion, seizure, and encephalopathy. Thus, the direct involvement of SARS-CoV-2 in the CNS has been studied in experimentally infected 3D neurospheres and brain organoids, which model the early characteristics of neurogenesis and the human cortical brain, respectively. Evidence provided independently using these 3D systems support autopsy findings that the human brain is permissive to SARS-CoV-2 infection and supports productive virus replication [49-51].

ACE2 expression was found to be low in human corneal and conjunctiva samples, which could explain the inferior susceptibility of these tissues to SARS-CoV-2 and the low frequency of conjunctivitis in COVID-19 patients [52]. Only 0 to 5.2\% of PCR-positive COVID-19 patients have detectable SARS-CoV-2 RNA in conjunctival swabs or tears [53,54]. However, these findings have been contested by others. Makovoz et al. (2020) used eye organoids and adult human ocular cells and found that ocular cells express ACE2 and TMPRSS2, essential proteins for SARS-CoV-2 viral entry, and that these cells are susceptible to the virus. They found higher levels of viral replication in the limbus (border of the cornea and the sclera) compared to the central cornea area [55]. 
Table 1. In Vitro and ex vivo models for severe acute respiratory syndrome coronavirus 2 (SARS-CoV-2) studies.

\begin{tabular}{|c|c|c|c|c|}
\hline Cell/Tissue Type & SARS-CoV-2 Strain & Viral Cultivation & Main Applications & References \\
\hline \multicolumn{5}{|c|}{ Two-dimensional (2D) Models: Immortalized Cells } \\
\hline Vero CCL-81 and Vero E6 & $\begin{array}{c}\text { 2019- } \\
\text { nCoVBetaCoV/Wuhan/WIV04/2019; } \\
\text { BetaCoV/Korea/SNU01/2020; } \\
\text { SARS-CoV-2/USA-WA1/2020; } \\
\text { Australia/VIC01/2020; } \\
\text { C-Tan-nCoV Wuhan strain 01 }\end{array}$ & $\begin{array}{l}\text { Vero cells used in viral isolation were cultured as } \\
\text { monolayers in flasks at } 37^{\circ} \mathrm{C} \text { and } 5 \% \text { atm of carbon } \\
\text { dioxide }\left(\mathrm{CO}_{2}\right) \text { in Dulbecco's Modified Eagle Medium } \\
\text { (DMEM) or Earle's Minimum Essential Medium } \\
\text { (EMEM) supplemented with } 2 \text { to } 10 \% \text { fetal bovine } \\
\text { serum (FBS). Some authors cite extra supplementation } \\
\text { with antibiotics and buffers. Cytopathic effect could be } \\
\text { observed in } 2 \text { to } 6 \text { days of infection (d.p.i.) or after } \\
\text { another viral passage. Protocols for antiviral assays } \\
\text { include cultivation in microplates with different values } \\
\text { for multiplicity of infection (MOI). }\end{array}$ & $\begin{array}{l}\text { Virus isolation of different } \\
\text { SARS-CoV-2 strains; infection } \\
\text { characterization; evaluation of host } \\
\text { responses; evaluation of antiviral } \\
\text { activity; vaccine production. }\end{array}$ & {$[15-19,25-30]$} \\
\hline Huh-7 & $\begin{array}{l}\text { 2019-nCoV } \\
\text { BetaCoV/Wuhan/WIV04/2019; } \\
\text { SARS-CoV-2/USA-WA1/2020 }\end{array}$ & $\begin{array}{l}\text { Huh- } 7 \text { cells were cultured in DMEM supplemented } \\
\text { with } 10 \% \text { FBS at } 37{ }^{\circ} \mathrm{C} \text { and } 5 \% \text { atm } \mathrm{CO}_{2} \text {. Some authors } \\
\text { have reported supplementation with antibiotics and } \\
\text { antimycotics. For antiviral assays, MOI } 0.01 \text { was used, } \\
\text { and the supernatant was collected after } 48 \mathrm{~h} \text {. }\end{array}$ & $\begin{array}{l}\text { SARS-CoV-2 isolation; infection } \\
\text { characterization; evaluation of host } \\
\text { responses; evaluation of antiviral } \\
\text { activity. }\end{array}$ & {$[15,28]$} \\
\hline Calu-3 & SARS-CoV-2/USA-WA1/2020 & $\begin{array}{l}\text { Calu- } 3 \text { cells were cultured in DMEM supplemented } \\
\text { with } 10 \text { or } 20 \% \text { FBS at } 37^{\circ} \mathrm{C} \text { and } 5 \% \text { atm } \mathrm{CO}_{2} \text {. Some } \\
\text { authors have reported supplementation with } \\
\text { antibiotics and antimycotics. SARS-CoV-2 was infected } \\
\text { at MOI } 0.01 \text { or } 0.001 \text { and viral presence was evaluated } \\
\text { at } 24,48 \text {, or } 72 \text { h post-infection. }\end{array}$ & Evaluation of antiviral activity. & [28] \\
\hline A549-ACE2 & SARS-CoV-2/USA-WA1/2020 & $\begin{array}{l}\text { A549 cells were maintained at } 37^{\circ} \mathrm{C} \text { and } 5 \% \text { atm of } \\
\mathrm{CO}_{2} \text { and cultured in DMEM supplemented with } 10 \% \\
\text { Serum Plus II. SARS-CoV-2 was infected at MOI } 0.1 \text { for } \\
36 \mathrm{~h} \text {. }\end{array}$ & $\begin{array}{l}\text { Mapping of genes that are } \\
\text { associated with SARS-CoV-2 } \\
\text { infection. }\end{array}$ & {$[24]$} \\
\hline
\end{tabular}


Table 1. Cont.

\begin{tabular}{|c|c|c|c|c|}
\hline Cell/Tissue Type & SARS-CoV-2 Strain & Viral Cultivation & Main Applications & References \\
\hline \multicolumn{5}{|c|}{ Three-dimensional (3D) Models: Explants and Organoids } \\
\hline $\begin{array}{l}\text { Human nasal } \\
\text { epithelial cells (HNE), bronchial } \\
\text { epithelial cells (large airway } \\
\text { respiratory cells_LAE), bronquiolar } \\
\text { epithelial cells (small airway } \\
\text { respiratory-SAE) }\end{array}$ & SARS-CoV-2/USA-WA1/2020 & $\begin{array}{l}\text { HNE cells were grown in an air-liquid system (ALI) } \\
\text { system. LAE and SAE cells were initially co-cultured } \\
\text { with mitomycin-treated } 3 \text { T3 J } 2 \text { cells in DMEM then } \\
\text { passed to an ALI system. After cultivation, the viruses } \\
\text { were inoculated at MOI } 0.5 \text { and 3. Cytopathic effect } \\
\text { not described. Viral titers were described } 24 \mathrm{~h} \\
\text { post-infection. }\end{array}$ & $\begin{array}{l}\text { SARS-CoV-2 isolation; infection } \\
\text { characterization; evaluation of host } \\
\text { responses. }\end{array}$ & {$[19,36]$} \\
\hline $\begin{array}{l}\text { Human alveolar epithelial cells } \\
\text { (AECs) }\end{array}$ & $\begin{array}{c}\text { BetaCoV/Hong } \\
\text { Kong/VM20001061/2020 }\end{array}$ & $\begin{array}{l}\text { Culture of primary cells in flasks. AECs were infected } \\
\text { with SARS-CoV-2 at MOI } 0.1 \text { or } 2 \text {. Detection of viral } \\
\text { RNA after } 24 \mathrm{~h} \text {. }\end{array}$ & $\begin{array}{l}\text { Infection characterization; } \\
\text { evaluation of host responses. }\end{array}$ & [10] \\
\hline $\begin{array}{l}\text { Normal human bronchial epithelial } \\
\text { cells (NHBE) }\end{array}$ & SARS-CoV-2/USA-WA1/2020 & $\begin{array}{l}\text { ALI system was not mentioned as a cultivation } \\
\text { mechanism. NHBE cells were cultured in bronchial } \\
\text { epithelial growth medium supplemented with BEGM } \\
\text { SingleQuots. SARS-CoV-2 was infected at MOI } 2 \text { for } \\
24 \text { h. }\end{array}$ & $\begin{array}{l}\text { Infection characterization; } \\
\text { evaluation of host responses. }\end{array}$ & [41] \\
\hline Adult human ocular cells & SARS-CoV-2/USA-WA1/2020 & $\begin{array}{l}\text { Ocular tissue was maintained in DMEM/F-12 } \\
\text { supplemented with FBS and ROCK inhibitor. } \\
\text { SARS-CoV-2 was infected in MOI } 1 \text { for } 24 \mathrm{~h} \text {. The } \\
\text { titrations were performed with Vero E6 cells. Real-time } \\
\text { quantitative polymerase chain reaction (qRT-PCR) was } \\
\text { also used for analysis. }\end{array}$ & $\begin{array}{l}\text { Infection characterization; } \\
\text { evaluation of host responses. }\end{array}$ & [55] \\
\hline $\begin{array}{l}\text { Human neural progenitor cells } \\
\text { (hNPCs) }\end{array}$ & $\begin{array}{c}\text { SARS-CoV-2 HKU-001a; SARSCoV } \\
\text { GZ50 }\end{array}$ & $\begin{array}{l}\text { hNPCs are derived from induced pluripotent stem } \\
\text { cells (iPSCs) grown in mTeSRTM1 medium induced by } \\
\text { a cocktail of supplements. After this induction, the } \\
\text { cells were cultured in 1:1 DMEM/F-12 and neurobasal } \\
\text { medium with extra supplementation. SARS-CoV-2 } \\
\text { was infected in a MOI } 10 \text { and the infection analyzed by } \\
\text { qRT-PCR. }\end{array}$ & Infection characterization. & [51] \\
\hline
\end{tabular}


Table 1. Cont

\section{Cell/Tissue Type}

SARS-CoV-2 HKU-001a; SARSCoV GZ50
Brain organoids

SARS-CoV-2 HKU-001a; SARSCoV GZ50

\section{Viral Cultivation}

Main Applications

References

Neurospheres are derived from iPSCs and were

isolated using Accutase and then maintained in Iscove's Modified Dulbecco's Medium (IMDM)

supplemented with $15 \%$ FBS and additional

components. After the formation of the embryoid body

(EB), the rosettes were formed in 96-well plates

containing DMEM/F12 medium supplemented with

fibroblast growth factor 2 (FGF2) and Gem 21

NeuroPlex. The formation of neurospheres is given by

the rotation of cells without FGF2. A virus title of

$2.6 \times 10^{6}$ p.f.u. $/ \mathrm{mL}$ were used to infect the

neurospheres. Plates and qRT-PCR assays were

performed to detect and quantify SARS-CoV-2.

Brain organoids are derived from iPSCs (from donors or not) and were isolated using Accutase and then kept in supplemented mTeSR1 medium for three days,

where a series of changes in

place to form organoids. A $2.6 \times 10^{6}$ p.f.u. $/ \mathrm{mL}$ virus

titer or supernatant of SARS-CoV-2 cultivar was used

to infect the organoids. qRT-PCR plates and assays were performed to detect and quantify SARS-CoV-2.

Liver organoids were derived from human pluripotent

stem cells (hPSCs), which were cultured in Matrigel

medium and differentiated with Activin A, BMP-4,

Liver organoids

SARS-CoV-2/USA-WA1/2020

bFGF and hepatocyte growth factor. SARS-CoV-2 was

Infection characterization

infected with MOI 0.01, 0.05, and 0.1. The titration

were performed with Vero E6 and HEK293 cells.

qRT-PCR was also used for analysis.

Kidney organoids were derived from human

pluripotent stem cells (hPSCs), which were cultured in

RPMI medium with multiple supplements.

Infection characterization

SARS-CoV-2 was infected at $10^{3}$ or $10^{5}$ viral particles

Infection characterization. and quantified by qRT-PCR. 
Table 1. Cont.

\begin{tabular}{|c|c|c|c|c|}
\hline Cell/Tissue Type & SARS-CoV-2 Strain & Viral Cultivation & Main Applications & References \\
\hline Lung organoids & SARS-CoV-2/USA-WA1/2020 & $\begin{array}{l}\text { Lung organoids were derived from human pluripotent } \\
\text { stem cells (hPSCs), which were cultured in } \\
\text { supplemented DMEM/F12 medium. SARS-CoV-2 was } \\
\text { infected at MOI } 0.01 \text { for } 24 \text { h and quantified by } \\
\text { qRT-PCR. }\end{array}$ & $\begin{array}{c}\text { Infection characterization; } \\
\text { evaluation of antiviral activity. }\end{array}$ & [48] \\
\hline Colonic organoids & SARS-CoV-2/USA-WA1/2020 & $\begin{array}{l}\text { Colonic organoids were derived from human } \\
\text { pluripotent stem cells (hPSCs), which were cultured in } \\
\text { supplemented DMEM/F12 or RPMI1640 medium. } \\
\text { SARS-CoV-2 was infected at MOI } 0.01 \text { for } 24 \text { h and } \\
\text { quantified by qRT-PCR. }\end{array}$ & $\begin{array}{c}\text { Infection characterization; } \\
\text { evaluation of antiviral activity. }\end{array}$ & [48] \\
\hline Blood vessels organoids & $\begin{array}{c}\text { SARS-CoV- } \\
\text { 2/human/SWE/01/2020 }\end{array}$ & $\begin{array}{l}\text { Blood vessels organoids were derived from human } \\
\text { pluripotent stem cells (hPSCs). SARS-CoV-2 was } \\
\text { infected at } 10^{2}, 10^{4} \text { or } 10^{6} \text { viral particles and quantified } \\
\text { by qRT-PCR. }\end{array}$ & Infection characterization. & [56] \\
\hline Eye organoids & SARS-CoV-2/USA-WA1/2020 & $\begin{array}{l}\text { Ocular organoids were derived from human } \\
\text { embryonic stem cells (hESCs), which were cultured in } \\
\text { mTeSR } 1 \text { medium for } 10 \text { days and exchanged for SEAM } \\
\text { differentiation media to form ocular organoids. } \\
\text { SARS-CoV-2 was infected in MOI } 1 \text { for } 24 \mathrm{~h} \text {. The } \\
\text { titrations were performed with Vero E6 cells. qRT-PCR } \\
\text { was also used for analysis. }\end{array}$ & $\begin{array}{l}\text { Infection characterization; } \\
\text { evaluation of host responses. }\end{array}$ & [55] \\
\hline Bronquial tissue & $\begin{array}{c}\text { BetaCoV/Hong } \\
\text { Kong/VM20001061/2020 }\end{array}$ & $\begin{array}{l}\text { Bronquial tissue were maintained on F12K medium in } \\
\text { ALI system. The authors cite extra supplementation } \\
\text { with antibiotics and buffers. SARS-CoV-2 was infected } \\
\text { for } 1 \mathrm{~h} \text { at } 37^{\circ} \mathrm{C} \text { and washed with PBS buffer after that } \\
\text { time. Supernatant samples were collected after } 1,24 \text {, } \\
48,72 \text {, and } 96 \mathrm{~h} \text { post-infection. The titrations were } \\
\text { performed with Vero E6 or MDCK cells. Histological } \\
\text { and immunohistochemical analyzes were also } \\
\text { performed. }\end{array}$ & Infection characterization. & [10] \\
\hline
\end{tabular}


Table 1. Cont.

Cell/Tissue Type

Lung tissue

BetaCoV/Hong

Kong/VM20001061/2020;

SARS-CoV-2/human/HKG/HKU-

$001 \mathrm{a} / 2020$

\section{Viral Cultivation}

Main Applications

References

Lung tissue fragments were maintained on

supplemented DMEM/F12 medium in plaques or

supplemented F12K medium in an ALI system.

SARS-CoV-2 was infected for 1 or $2 \mathrm{~h}$ at $37^{\circ} \mathrm{C}$ and then

washed with PBS buffer. Supernatant samples were

Infection characterization

.

Histological and immunohistochemical analyzes were also performed.

Conjunctiva tissue were maintained on supplemented

F12K medium in an ALI system. SARS-CoV-2 was

infected for $1 \mathrm{~h}$ at $33^{\circ} \mathrm{C}$ and then washed with PBS

buffer. Supernatant samples were collected after 1, 24,

48,72 , and $96 \mathrm{~h}$ post-infection. Titrations were

Infection characterization.

performed with Vero E6 or MDCK cells. Histological

and immunohistochemical analyzes were also

performed.

d.p.i.: days post infection; MOI: Multiplicity of infection; atm: atmosphere; FBS: Fetal bovine serum; p.f.u.: plaque-forming unit 
Epithelial cells of human renal proximal tubules (KPTEC) were cultured using a 2D conditional reprogramming system (CR) and 3D organoids cultures as physiological ex vivo kidney models. ACE2 expression in 2D CR culture was about half the one observed in 3D organoids culture. Pseudovirion assays with a SARS-CoV spike (S) protein construct demonstrated that CR KPTECs were permissive for SARS-CoV infection, suggesting that these models could be used to study SARS-CoV-2 nephropathology [9]. Susceptibility of 3D kidney organoids derived from human embryonic stem cells to SARS-CoV-2 infection has been directly confirmed [56].

Cumulative evidence from basic research and clinical studies has recognized COVID-19 as a multisystem disorder that also affects the vascular system. Monteil and co-workers engineered human capillary organoids from induced pluripotent stem cells (iPSCs) and demonstrated that human blood vessel organoids could be readily infected by SARS-CoV$2[56]$.

\section{Animal Models}

An appropriate animal model develops the desired viral infection with clinical signs similar to those observed in humans. It is possible to elucidate virus biology and the mechanisms of infection using in vivo approaches, thus allowing the development of new drugs and vaccines. Therefore, the prevention and control of SARS-CoV-2 require the establishment of appropriate animal models for viral study [57]. Experimental studies have demonstrated that mice, hamster, rabbits, bats, cats, dogs, ferrets, and non-human primates can be infected by SARS-CoV-2 [58]. The following sections describe the most important animal models currently being used in SARS-CoV-2 research and their main characteristics are summarized in Tables $2-4$.

\subsection{Mice}

ACE2 is the receptor used by SARS-CoV-2 to enter human cells [14]. SARS-CoV-2 presents a high affinity for human ACE2, but low affinity for ACE2 from other organisms [59]. Previous studies have shown that SARS-CoV-1 does not replicate efficiently in wild-type mice, thus requiring animal adaptation via serial viral passages or the development of transgenic mouse models capable of expressing human ACE2 [60-64]. This limitation of viral replication in wild-type mice can also be observed in animals infected with SARS-CoV-2, since there are no efficient interactions between the viral Spike protein (S) and the murine ACE2 [15]. Mice expressing human ACE2 (hACE2) were generated using CRISPR/Cas9 technology. Young or aged, wild-type or hACE2-producing C57BL/ 6 mice were infected intranasally with SARS-CoV-2. Infected hACE2 mice developed high viral loads in trachea, lung, and brain. Although no deaths were observed, aged hACE2 mice presented interstitial pneumonia and elevated cytokine levels. After intragastric virus inoculation, a productive infection was observed, which led to pathological pulmonary changes in these animals [65].

Previous studies with SARS-CoV-1 have developed a transgenic mouse called HFH4hACE2, generated from C3B6 mice. This mouse expresses hACE2 under the control of HFH4/FOXJ1 promoter on lung ciliated epithelial cells $[61,66]$. This model expressed high levels of hACE2 in the lung, but different levels in other tissues, including brain, liver, kidney and gastrointestinal tract. Infected mice can lose more than $20 \%$ of body weight and die due to lethal encephalitis [61]. This model was recently applied in studies with SARS-CoV-2. Infected animals had typical interstitial pneumonia and clinical signs similar to those observed in COVID-19 patients. The virus was detected in the lungs, the main site of infection, although viral RNA has also been found in the eye, heart, and brain of some animals. Pre-exposure to SARS-CoV-2 was able to protect mice from re-infection [67].

hACE2 mice infected intranasally with SARS-CoV-2 showed up to $8 \%$ of weight loss until $5 \mathrm{dpi}$. Animals also showed bristled fur, lordosis position and decreased response to external stimuli. Viral loads were detected in the lungs at 1, 3, 5, and 7 dpi. Interestingly, viral RNA was detectable $1 \mathrm{dpi}$ in the intestine but not in the following days. Although 
viral loads were detected in the intestine, no virus was isolated, suggesting that a residual inoculum reached the intestine by swallowing. Histopathological exams showed that animals developed interstitial pneumonia, presence of scattered dark reddish-purple areas in the lung, and palpable nodules in the lungs [68].

hACE2 interaction with human TMPRSS2 (hTMPRSS2) improves cellular entry of SARS-CoV [69]. Recently, it has been discovered that hTMPRSS2 is also important for priming of SARS-CoV-2 protein $S$ and inhibition of this protease prevents viral cell entry [14]. New studies may be carried out considering the development of mouse models expressing both hTMPRSS2 and hACE2, which could create a new transgenic lineage capable of effectively recapitulating the disease [70].

Another approach to circumvent the absent affinity of SARS-CoV-2 for mouse ACE2 (mACE2) is using reverse genetics to remodel the protein S-mACE2 binding interface. This resulted in a recombinant virus (SARS-CoV-2 MA) capable of using mACE2 for entering cells. SARS-CoV-2 MA was able to replicate in the upper and lower airways of young and adult BALB/c wild-type mice. Aged mice showed a more pronounced disease [71]. SARS-CoV-2 MA infection resulted in high viral titers in lung tissue $2 \mathrm{dpi}$, but the virus was rapidly eliminated 4 dpi under the same conditions, parental SARS-CoV-2 virus was not infectious for the mice. Airway inflammation was observed in histopathological analysis performed $2 \mathrm{dpi}$, associated with high levels of viral antigen staining [72].

Pulmonary transduction of mice with viral vectors encoding human ACE2 has successfully rendered conventional mice susceptible to SARS-CoV-2 infection, clinical disease and lung pathology. This approach offers the advantage of using commercially available mouse strains from multiple backgrounds and genetic modifications. Viral vectors that have been used so far for transducing mouse lungs with hACE2 include replication-defective human adenovirus 5 (Ad5) [73], adeno-associated virus (AAV) [74], and Venezuelan equine encephalitis replicon particles (VEEV) [75].

Recently, Rathnasinghe et al. compared side by side the replication and morbidity of K18-hACE2 transgenic model to adenovirus vector-mediated delivery of hACE2 to the mouse lung. They demonstrated that hACE2 adenovirus-transduced mice infected with SARS-CoV-2 had no clear clinical signs of disease, and lower viral replication was limited to the nasal turbinates and lung. In contrast, K18-hACE2 mice developed a severe disease with high lethality manifested by weight loss, lethargy, ruffled fur, hunched posture, and labored breathing. These transgenic animals also had 2 to 3 logs higher levels of viral replication in the nasal turbinates, lung and brain compared to the transduced model [76].

Virus adaptation to non-human organisms via serial passages can also be used to develop a mice-infectious strain. SARS-CoV-2 was inoculated on BALB/c mice using the intranasal route and the virus was recovered from pulmonary homogenates. Viral RNA was detected at high levels from the third passage and remained high until the sixth passage. The strain obtained in the sixth passage was then inoculated in groups of young (6-weeks-old) and aged (6-months-old) mice. The adapted SARS-CoV-2 efficiently infected both young and aged mice resulting in moderate pneumonia and inflammatory responses. This animal model was used for testing the effectiveness of an anti-SARS-CoV-2 vaccine based on RBD subunit. The vaccine prototype triggered antibody production, showed potent neutralizing effects, and conferred total protection against the infection [77].

\subsection{Golden Syrian Hamsters}

The golden Syrian hamster (Mesocricetus auratus) is an animal model widely used in studies with SARS-CoV due to its permittivity to this viral infection [62]. The SARS-CoV2-binding domain of ACE2 presents a high degree of similarity between hamsters' and humans' receptors, encouraging the use of golden Syrian hamsters in SARS-CoV-2 studies [78], despite the lack of certain reagents for immunological studies in this species. These animals presented viral replication in the lungs after SARS-CoV-2 intranasal inoculation. Histopathological analysis showed that the lungs developed marked pulmonary edema, inflammation, and cell death. Infected hamsters lost weight and showed an increased res- 
piratory rate [79]. Immunohistochemistry evaluations of hamsters inoculated intranasally with SARS-CoV-2 demonstrated the presence of viral antigens in the nasal and bronchial mucosa, epithelial cells and in areas of pulmonary consolidation 2 and 5 dpi, followed by pneumocyte hyperplasia $7 \mathrm{dpi}$. Viral antigens were also observed in duodenum epithelial cells and viral RNA was detected in feces [80]. Moreover, Syrian hamsters developed a strong neutralizing antibody response against SARS-CoV-2, which provides immunity to subsequent virus rechallenge [81]. The role of STAT2 in SARS-CoV-2 infection has been demonstrated using a genetically engineered hamster model. STAT2-knockout hamsters have higher viral pulmonary titers, viremia, and systemic spread when compared to wild type animals. This indicates the importance of STAT2 in attenuate viral dissemination in the body. Therefore, STAT2-knockout hamsters had lower leukocyte infiltration, reduced pulmonary pathology, and absence of pneumonia [82].

The hamster model can mirror certain epidemiological features of COVID-19 in humans, such as the effect of age and sex in the severity of the disease. Thus, the age of experimental animals should be considered during the development of a hamster model for SARS-CoV-2 infection. Osterrieder et al. followed the course of SARS-CoV-2 infection in young and aged Syrian hamsters. Although viral replication in the upper and lower respiratory tract occurred regardless of animals' age, hamsters infected at older ages experienced a more pronounced weight loss compared to younger animals. Histopathological analysis showed an important age-dependent influx of immune cells into the lungs, which happened earlier and stronger in young animals. Older hamsters developed conspicuous alveolar and perivascular edema, which indicates vascular leakage. Young animals had a rapid recovery from $14 \mathrm{dpi}$ [83]. Studies using hamsters have also shown that infected animals transmitted the virus to healthy animals when co-housed. Although the infected animals exhibited a milder disease, hamsters can still be considered potential models for transmissibility studies [79].

Syrian hamsters were also used in the evaluation of transmission considering the use of masks. For this, the animals were placed in parallel cages in a closed system separated by a porous polyvinyl chloride air partition with unidirectional air flow. To assess the transmissibility of the virus, a surgical mask was placed between the cages. In the absence of the mask between the cages, the rate of transmission between animals was $66.7 \%$ while in the presence of the mask the rate of transmission decreased significantly to $16.7 \%$. Histopathological changes, the amount of virus found in the respiratory tract and the expression of antigens in naive hamsters protected by the mask were significantly milder than in shredded hamsters [84].

Lastly, Syrian hamsters have proven to be a suitable to evaluate vaccines [85-87] and antiviral drugs [88-90] against SARS-CoV-2. 
Table 2. Mouse models used in SARS-CoV-2 studies.

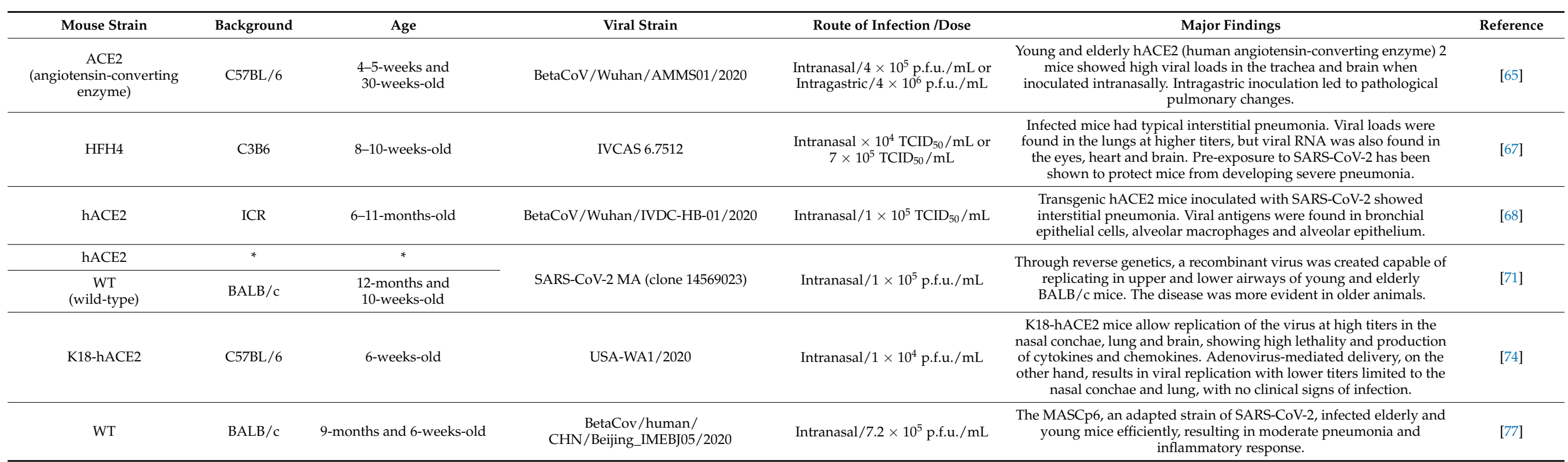

${ }^{*}$ Not reported; p.f.u.: plaque formation unit; TCID $_{50}$ : Median Tissue Culture Infective Dose; WT: wild-type. 


\subsection{Ferrets}

Ferrets (Mustela putorius furo) are a popular model for respiratory infections because their lung physiology and pathological response resembles that of humans. Unlike mice and rats, ferrets exhibit the cough reflex [91] and are widely used as a model for transmission and pathogenesis of respiratory viruses. Since coughing is the most frequently reported symptom in cases of SARS-CoV-2 infection, these animals represent good models for COVID-19 [92]. Similar to hamsters, ferrets are a well-suited animal model for testing medical countermeasures against SARS-CoV-2, including drugs [93] and vaccines [94]. SARS-CoV-2 intranasal inoculation in ferrets led to viral RNA detection in nasal lavages after 2, 4, 6, and 8 days. Viral RNA was also detected in some rectal swabs, although copy numbers were notably lower than those from nasal samples. Some animals showed fever and appetite loss between 10 and $12 \mathrm{dpi}$. However, the analysis of the collected organs did not detect viral RNA. Pathological investigation revealed severe perivasculitis and lymphoplasmacytic vasculitis, increased number of type II pneumocytes, macrophages and neutrophils in the alveolar septa and lumen and mild peribronchitis in the lungs of sacrificed ferrets $13 \mathrm{dpi}$. Ferrets infected through trachea showed viral RNA in the nasal turbinate and soft palate 2, 4, and $8 \mathrm{dpi}$ and in amygdala and trachea only $8 \mathrm{dpi}$ [95]. These results together with the data obtained from the evaluation of infection response in ferrets after inoculation of different viral loads, demonstrated that SARS-CoV-2 can replicate in the upper respiratory tract of these animals, showing a disease pattern similar to humans [96].

In a transmissibility assay, intranasal inoculation of SARS-CoV-2 collected from donor ferrets resulted in respiratory tract infection of recipient animals between 11 and 19 days after inoculation. When transmitted via direct contact between animals, the virus compromised the animals' respiratory tract 1 to 3 days after exposure. Transmission was also evaluated among independent indirect recipients; animals were disposed in a different compartment separated from infected ferrets by a wall that allowed for air circulation. In these animals, infection was observed between 3 and 7 days. The pattern of viral dissemination in direct and indirect contacts was similar to that observed in inoculated ferrets. Infectious particles could be isolated from all animals, showing that any route was able to infect ferrets efficiently [97]. In another study, naive ferrets kept in direct contact with infected ferrets showed signs of infection such as rise in body temperature between 2- and 6-days post exposure. Ferrets placed in indirect contact with infected animals did not show clinical signs of the disease. However, some indirect contacts were positive for viral RNA, which indicates possible air transmission. Pulmonary histology of ferrets showed only signs of inflammatory process that occurred $4 \mathrm{dpi}$ [98].

Ferrets were also used for assessing the immune response against SARS-CoV-2 after intranasal inoculation. Compared to influenza A infection, SARS-CoV-2 triggered a milder airway immune response. This data was compared to results obtained in humans, using lung samples from post-mortem COVID-19 patients. The analysis showed that genes significantly induced in response to SARS-CoV-2 included a subset of interferon-stimulated gene (ISGs), but not INF-I or IFN-III. SARS-CoV-2 also induced high levels of chemokines, such as CCL2, CCL8, and CCL11. The immune response observed in human samples was similar for ferrets. However, the authors did not report respiratory or systemic pathological signs in the SARS-CoV-2 infected ferrets, suggesting a major limitation in the use of these animals for pathology studies [41].

\subsection{Dogs}

Although dogs present low susceptibility to SARS-CoV-2 infection, these animals can be infected when in contact with COVID-19 human patients. Dogs express ACE2, but there is a single mutation (H34Y) in the canine ACE2 receptor that is not found in human or feline ACE2 and this residue appears to be critical to the low susceptibility of dogs to SARS-CoV-2 [99].

Soon after SARS-CoV-2 emerged in Hong Kong, the Department of Agriculture, Fisheries and Conservation (AFCD) offered the option for pet owners to have their dogs and 
cats looked after and tested for SARS-CoV-2. Fifteen dogs from households with confirmed COVID-19 cases were tested and two asymptomatic dogs (a 17-years-old neutered male Pomeranian and a 2.5-years-old male German shepherd) were found positive in nasal swabs samples. Immune responses were detected in both dogs using plaque reduction neutralization assays. Molecular analyzes showed that the genome of the viruses isolated from the two dogs were identical to the virus detected in human tutors, suggesting a human-animal transmission of SARS-CoV-2 [100].

Dogs have also been infected with SARS-CoV-2 under experimental conditions. Five three-month-old Beagle dogs were infected with SARS-CoV-2. The virus was inoculated intranasally and the directly infected dogs were allocated together with uninfected animals. Oropharyngeal and rectal swabs were collected 2, 4, 6, 8, 10, 12, and 14 dpi for RNA detection and virus titration. Viral RNA was detected in rectal samples from two dogs 2 dpi and one $\operatorname{dog} 6$ dpi. The dog positive for viral RNA in the rectal sample was sacrificed, but the organs and tissues collected did not have viral RNA. Only two dogs seroconverted, indicating the low susceptibility of these animals to SARS-CoV-2 infection [95]. Although dogs do not develop clinical disease, once inoculated, there is the development of a neutralizing antibody response that begins 14 days after inoculation, peaking at 21 day [101]. A recent study in which dogs were intranasally infected with SARS-CoV-2 showed that the animals seroconverted and mounted a specific neutralizing antibody response, but did not shed the virus upon infection [102].

To date, there is no substantial evidence to support that dogs infected with SARSCoV-2 can transmit the virus to humans [102], and most dog infections seems to have been acquired from infected humans [103].

\subsection{Cats}

During COVID-19 outbreak in Wuhan, cases of domestic cats infected with SARSCoV-2 were reported. Cats were diagnosed by serology assays. Infection in cats can occur after contact with COVID-19 patients or due to environmental contamination [104]. Recent studies have shown that domestic cats are susceptible and that infected animals can efficiently transmit SARS-CoV-2 to healthy animals $[95,102,105]$.

Groups of young cats (6-9 months old) and adults (10-14 years old) inoculated via intranasal route had the virus detected in the upper and lower airways. Although the animals did not show signs of the disease, necropsy exams detected interstitial pneumonia, loss of eyelashes and epithelial necrosis, as well as inflammation in the nasal turbinate and trachea. In a group of 10 young cats, two animals died on the third and 13th day after infection. Virus antigen was present in the nasal concha epithelium and necrotic debris was found in the amygdala, submucosal trachea glands, and small intestine enterocytes [95]. Similar findings have been independently obtained from adult animals (5-8 years old) [102]

Cat-to-cat transmission has been reported. Airway samples from healthy cats presented viral RNA after they have been exposed to infected animals [95,102]. There is still no solid evidence proving that cats infected with SARS-CoV-2 are capable of transmitting the virus to humans, although the high levels of viral shedding $\left(10^{6} \mathrm{pfu} / \mathrm{mL}\right)$ in nasal and oropharyngeal swabs for up 10 days is worrisome [102]. 
Table 3. Non-murine models for SARS-CoV-2 studies (except non-human primates).

\begin{tabular}{|c|c|c|c|c|c|}
\hline Animal Species & Age & Viral Strain & Route of Infection/Dose & Major Findings & Reference \\
\hline \multirow{5}{*}{ Syrian hamster } & 6-10-weeks-old & * & Intranasal $/ 10^{5}$ p.f.u. $/ \mathrm{mL}$ & $\begin{array}{l}\text { Animals challenged with SARS-CoV-2 showed viral } \\
\text { replication, severe edema, inflammation and cell } \\
\text { death in the lungs. The animals also showed weight } \\
\text { loss and increased respiratory rate. }\end{array}$ & [79] \\
\hline & 4-5-weeks-old & $\begin{array}{c}\text { BetaCoV/Hong } \\
\text { Kong/VM20001061/2020 }\end{array}$ & $\begin{array}{l}\text { Intranasal } / 8 \times 10^{4} \\
\quad \operatorname{TCID}_{50} / \mathrm{mL}\end{array}$ & $\begin{array}{l}\text { Viral antigens were observed in the nasal mucosa, } \\
\text { bronchial epithelial cells, duodenal epithelial cells } \\
\text { and lung of infected hamsters. Rapid viral clearance } \\
\text { and pneumocyte hyperplasia were also found. }\end{array}$ & [80] \\
\hline & $\begin{array}{l}\text { 1-month-old and } \\
6-7 \text {-months-old }\end{array}$ & $\begin{array}{l}\text { SARS-CoV-2/UT-NCGM02/ } \\
\text { Tóquio and } \\
\text { SARS-CoV-2/UW- } \\
\text { 001/Human/2020/Wisconsin }\end{array}$ & $\begin{array}{l}\text { Intranasal and ocular } / 10^{3} \\
10^{5}, 10^{6} \text { p.f.u. } / \mathrm{mL}\end{array}$ & $\begin{array}{l}\text { SARS-CoV-2 isolates replicated efficiently in the } \\
\text { animals' lungs, causing severe lung disease. Serious } \\
\text { lung injuries were observed. Infected hamsters } \\
\text { developed neutralizing antibody responses that } \\
\text { prevented infection after viral re-exposure. }\end{array}$ & [81] \\
\hline & $\begin{array}{l}\text { 6-8-weeks and } \\
\text { 7-12-weeks-old }\end{array}$ & $\begin{array}{c}\text { BetaCov/Belgium/GHB- } \\
\text { 03021/2020 }\end{array}$ & $\begin{array}{c}\text { Intranasal } / 2 \times 10^{5} \\
\mathrm{TCID}_{50} / \mathrm{mL} \text { or } 2 \times 10^{6} \\
\mathrm{TCID}_{50} / \mathrm{mL}\end{array}$ & $\begin{array}{l}\text { Infected wild-type hamsters showed } \\
\text { bronchopneumonia and pulmonary inflammatory } \\
\text { response with neutrophil infiltration and edema. }\end{array}$ & [82] \\
\hline & 6-10-weeks & * & Intranasal $/ 10^{5}$ p.f.u. $/ \mathrm{mL}$ & $\begin{array}{l}\text { Surgical mask partition for challenged index or } \\
\text { naive hamsters significantly reduced the } \\
\text { transmission to } 25 \% \text {. Surgical mask partition for } \\
\text { challenged index hamsters significantly reduced } \\
\text { transmission to only } 16.7 \% \text { of exposed naive } \\
\text { hamsters. }\end{array}$ & [84] \\
\hline
\end{tabular}


Table 3. Cont

\begin{tabular}{|c|c|c|c|c|c|}
\hline Animal Species & Age & Viral Strain & Route of Infection/Dose & Major Findings & Reference \\
\hline \multirow{5}{*}{ Ferrets } & 3-4-months-old & $\begin{array}{l}\text { F13/environnment/2020/ } \\
\text { Wuhan and } \\
\text { CTan/human/2020Wuhan }\end{array}$ & Intranasal $/ 1 \times 10^{5}$ p.f.u. $/ \mathrm{mL}$ & $\begin{array}{l}\text { Viral RNA was found in nasal washes and rectal } \\
\text { swabs from infected ferrets. Fever and appetite loss } \\
\text { were observed in some animals. However, RNA } \\
\text { was not detected in animals' organs. }\end{array}$ & [95] \\
\hline & 7-months-old & Victoria/01/2020 & Intranasal $/ 5 \times 10^{2} / 10^{4} / 10^{6}$ p.f.u & $\begin{array}{l}\text { High and medium viral doses induced a consistent } \\
\text { viral infection in the animals' upper respiratory } \\
\text { ' tract, causing bronchopneumonia (high dose) and } \\
\text { bronchointerstitial pneumonia (medium dose). }\end{array}$ & [96] \\
\hline & 6-months-old & BetaCoV/Munich/BavPat1/2020 & $\begin{array}{l}\text { Intranasal } / 6 \times 10^{5} \\
\quad \mathrm{TCID}_{50} / \mathrm{mL}\end{array}$ & $\begin{array}{l}\text { SARS-CoV-2 could be transmitted via direct contact } \\
\text { and via air (drops and/or aerosols) between ferrets. } \\
\text { Viral RNA was detected in infected animals directly } \\
\text { between } 1 \text { to } 3 \text { days after inoculation and after } 7 \\
\text { days in animals infected by indirect contact. }\end{array}$ & [97] \\
\hline & 12-20-months-old & NMC2019-nCoV02 & Intranasal $/ 10^{5} \mathrm{TCID}_{50} / \mathrm{mL}$ & $\begin{array}{l}\text { Infected ferrets exhibited elevated body } \\
\text { temperatures and viral replication. The virus was } \\
\text { retrieved from nasal samples, saliva, urine, and } \\
\text { feces. Viral RNA was detected in the nasal concha, } \\
\text { trachea, lungs, and intestine. The study } \\
\text { demonstrated the possibility of transmission by } \\
\text { direct or indirect contact. }\end{array}$ & [98] \\
\hline & 4-months-old & USA-WA1/2020 & Intranasal $/ 5 \times 10^{4}$ p.f.u. $/ \mathrm{mL}$ & $\begin{array}{l}\text { Infected ferrets showed low airway immune } \\
\text { responses when compared to Influenza A infection. }\end{array}$ & [41] \\
\hline \multirow[t]{2}{*}{ Dogs } & 3-months-old & CTam-H & Intranasal $/ 1 \times 10^{5}$ p.f.u. $/ \mathrm{mL}$ & $\begin{array}{l}\text { Infected dogs had viral RNA detected in rectal } \\
\text { samples, but viral RNA was not detected in any } \\
\text { other organ or tissue. The study demonstrated a } \\
\text { low susceptibility of dogs to SARS-CoV-2. }\end{array}$ & [95] \\
\hline & 5-6-years-old & WAI/2020WY96 & Intranasal $/ 1.4 \times 10^{5}$ p.f.u. $/ \mathrm{mL}$ & $\begin{array}{l}\text { Dogs inoculated with SARS-CoV-2 did not develop } \\
\text { an evident disease, but the production of } \\
\text { neutralizing antibodies after infection was found. }\end{array}$ & [102] \\
\hline
\end{tabular}


Table 3. Cont

Animal Species

$$
\text { Age }
$$

Viral Strain

CTam-H

70-days-old to 3-months-old

Cats

\section{Route of Infection/Dose}

\section{Major Findings}

The study showed that cats are susceptible to experimental infection and that virus can be transmitted to uninfected cats when housed together. The virus replicated only in the upper respiratory tract of infected cats, especially in

younger animals.
e findings showed that cats are highly susceptible

Intranasal $/ 1 \times 10^{5}$ p.f.u. $/ \mathrm{m}$ to infection by SARS-CoV-2 by maintaining a

prolonged period of oral and nasal viral release. It

6-8-years-old

WAI/2020WY96

Intranasal $/ 3 \times 10^{5}$ p.f.u. $/ \mathrm{mL}$

has been reported that infected cats develop neutralizing antibodies that prevent possible reinfection, but there are no clinical signs of the disease. The study also demonstrated the possibility of transition by direct contact between animals.
Reference

* Not reported; p.f.u.: plaque formation unit; TCID $_{50}$ : Median Tissue Culture Infective Dose; WT: wild-type. 


\subsection{Non-Human Primates}

Non-human primates (NHP) have been widely used to study SARS-CoV and MERS$\mathrm{CoV}$ infection and are being now explored for COVID-19 research. Studies were performed in cynomolgus macaques (Macaca fascicularis), African green monkeys (Chlorocebus aethiops), rhesus macaques (Macaca mulatta), and in the common marmosets (Callithrix jacchus) to better understand the disease pathogenesis, immunity, and testing suitable vaccine and therapeutic approaches [106-109]. Non-human primates are more phylogenetically similar models to humans than other animal models, and although this is an advantageous feature, it should be noted that studies with them generally use a limited number of individuals ( 1 or 2 animals per group). Therefore, the results obtained should be interpreted with caution [110].

Cynomolgus monkeys were used as a model to assess the pathogenesis of SARS$\mathrm{CoV}-2$ and other previous emerging coronaviruses infections. Animals inoculated with SARS-CoV-2 did not show clinical signs of the disease but developed diffuse alveolar damage in types I and II pneumocytes and damage to bronchial and bronchiolar mucosal epithelial cells. In SARS-CoV infection, lung lesions were more severe than those caused by SARS-CoV-2 and milder than those caused by MERS-CoV [106].

Rhesus monkeys infected by the intratracheal route with SARS-CoV-2 developed respiratory diseases between 8 and $16 \mathrm{dpi}$. High viral loads were detected in nose and throat samples and pulmonary infiltrates were observed after pulmonary radiography. Infected animals also presented viral RNA in samples from rectal swabs. In summary, rhesus monkey manifested a moderate disease similar to the ones observed in most human cases [107]. Ocular conjunctival route has also been evaluated as a form of infection in rhesus monkeys. The model was permissive to SARS-CoV-2 infection leading to mild pneumonia, with no cases of severe pneumonia or death [111].

Lu et al. compared the different susceptibilities of Old World (cynomolgus and rhesus macaques) and New World monkeys (marmosets) to SARS-CoV-2 infection and compared the clinical signs, viral shedding, and replication, and host responses to the infection. All three species were susceptible to SARS-CoV-2 infection as determined by viremia and viral shedding in nasal, pharyngeal, and anal swabs. A viral load was detected in the pulmonary tissues of cynomolgus and rhesus macaques, but not in marmosets. Marmosets were the least susceptible NPH and rhesus monkeys were found to be the most suitable model for COVID-19 as it most closely recapitulated the disease in human patients [108]. At the molecular level, differences in the amino acids sequences of host ACE2 partially explained the differences in susceptibility. M. mulatta and M. fascicularis have identical amino acids sequences to the human ACE2 region that binds to the RDB domain of the SARS-CoV-2, whereas the $C$. jacchus and humans differ by four amino acids. Mice and ferrets differ from this critical domain of the human ACE2 receptor by eight and seven amino acids, respectively [108].

African green monkeys infected by multiple mucosal routes (nasal, oral, ocular, and tracheal) or through aerosol exposure presented mild clinical infection that caused a transient decrease in pulmonary tidal volume. CT scan revealed lung lesions four days after infection. Infectious virus particles were eliminated by both respiratory and gastrointestinal tracts of all infected animals. Necropsy revealed viral RNA in both respiratory and gastrointestinal systems, with higher levels in the gastrointestinal tract. All infected animals presented anti-SARS-CoV-2 antibodies, and this high frequency of seroconversion has also been observed in human COVID-19 patients [109].

Viral replication in nasopharyngeal, anal, and lung samples is more active in aged monkeys than younger animals. When infected with SARS-CoV-2, monkeys develop typical interstitial pneumonia characterized by thickening of the alveolar septum accompanied by inflammation and edema. Nevertheless, diffuse severe interstitial pneumonia occurs mainly in aged monkeys. This data suggests that models of aged monkeys may be useful to mimic the most severe form of COVID-19 [112]. 
Table 4. Non-human primate models for SARS-CoV-2 studies.

\begin{tabular}{|c|c|c|c|c|c|}
\hline Animal Specie & Age & Viral Strain & Route of Infection/Dose & Major Findings & Reference \\
\hline $\begin{array}{l}\text { Cynomolgus macaques } \\
\text { (Macaca fascicularis) }\end{array}$ & $\begin{array}{l}\text { 4-5-years-old and } \\
15-20 \text {-years-old }\end{array}$ & * & Intratracheal and Intranasal/* & $\begin{array}{l}\text { SARS-CoV caused more severe lung injuries than } \\
\text { SARS-CoV-2 and milder infection than MERS-CoV in } \\
\text { these animals. }\end{array}$ & [106] \\
\hline $\begin{array}{l}\text { Rhesus macaques } \\
\text { (Macaca mulatta) }\end{array}$ & 3-5-years-old & WH-09/humam/2020/CHN & $\begin{array}{c}\text { Ocular Conjuctiva and } \\
\text { Intratracheal } / 1 \times 10^{6} \mathrm{TCID}_{50} / \mathrm{mL}\end{array}$ & $\begin{array}{l}\text { The conjunctival ocular route proved to be efficient for } \\
\text { infection of these animals, leading them to develop } \\
\text { mild pneumonia. However, the disease did not } \\
\text { manifest severely. }\end{array}$ & [111] \\
\hline $\begin{array}{c}\text { Rhesus macaques } \\
\text { (Macaca mulatta), Cynomolgus } \\
\text { macaques (Macaca fascicularis) } \\
\text { and Marmoset } \\
\text { (Callithrix jacchus) }\end{array}$ & * & * & $\begin{array}{c}\text { Intratracheal, Intranasal and } \\
\text { Conjuctiva } / 4.75 \times 10^{6} \text { p.f.u. } / \mathrm{mL} \text { and } \\
1 \times 10^{6} \text { p.f.u. } / \mathrm{mL}\end{array}$ & $\begin{array}{l}\text { Two families of monkeys from the Old World and one } \\
\text { from the New World were inoculated experimentally } \\
\text { with SARS-CoV-2. Among the studied species, } M \text {. } \\
\text { mulatta was the most susceptible to infection followed } \\
\text { by M. fascicularis and C. jacchus. }\end{array}$ & [108] \\
\hline $\begin{array}{l}\text { Rhesus macaques (Macaca } \\
\text { mulatta) }\end{array}$ & $3-5$-years and 15 -years-old & $\begin{array}{c}\text { BetaCoV/Wuhan/IVDC-HD- } \\
\text { 01/2020 }\end{array}$ & Intratracheal $/ 1 \times 10^{6} \mathrm{TCID}_{50} / \mathrm{mL}$ & $\begin{array}{l}\text { Viral replication occurred more effectively in elderly } \\
\text { monkeys, causing severe interstitial pneumonia. } \\
\text { Authors suggest that elderly monkeys are useful to } \\
\text { model the severe form of the disease. }\end{array}$ & [112] \\
\hline $\begin{array}{l}\text { Rhesus macaques (Macaca } \\
\text { mulatta) }\end{array}$ & $3-5$ years-old & * & Intratracheal $/ 1 \times 10^{6} \mathrm{TCID}_{50} / \mathrm{mL}$ & $\begin{array}{l}\text { SARS-CoV-2 reinfection was described and its signs } \\
\text { were presented. Authors suggest that an initial } \\
\text { infection prepares the immune system for a possible } \\
\text { new infection. }\end{array}$ & [113] \\
\hline $\begin{array}{l}\text { Rhesus macaques (Macaca } \\
\text { mulatta) }\end{array}$ & 6-12-years-old & * & $\begin{array}{c}\text { Intratracheal or } \\
\text { intranasal } / 1.1 \times 10^{4} \text { p.f.u. } / \mathrm{mL} \text { or } \\
1.1 \times 10^{5} \text { p.f.u. } / \mathrm{mL} \text { or } \\
1.1 \times 10^{6} \text { p.f.u. } / \mathrm{mL}\end{array}$ & $\begin{array}{l}\text { SARS-CoV-2 reinfection was described and its signs } \\
\text { were presented. Authors suggest that an initial } \\
\text { infection prepares the immune and humoral systems } \\
\text { for a possible new infection. }\end{array}$ & [114] \\
\hline $\begin{array}{l}\text { African green monkeys } \\
\text { (Chlorocebus aethiops) }\end{array}$ & $3-5$ years-old & $\begin{array}{l}\text { SARS-CoV-2/München- } \\
1.1 / 2020 / 929 \\
\text { (Munich) }\end{array}$ & $\begin{array}{l}\text { Intranasal, oral, ocular and } \\
\text { intratracheal } / 5 \times 10^{5} \text { p.f.u } / \mathrm{mL}\end{array}$ & $\begin{array}{l}\text { Infected young monkeys had low fever and the } \\
\text { respiratory symptoms were limited to a transient } \\
\text { decrease in tidal volume. Viral RNA was found in all } \\
\text { airways and gastrointestinal system. All animals } \\
\text { seroconverted simultaneously for IgM and IgG. }\end{array}$ & [109] \\
\hline
\end{tabular}

${ }^{*}$ Not reported; p.f.u.: plaque formation unit; $\mathrm{TCID}_{50}$ : Median Tissue Culture Infective Dose. 
A crucial question in COVID-19 immunity is whether a previously infected person can be re-infected and develop clinical signs of the disease. NPH models have been used to fill this knowledge gap. Chandrashekar et al. and Deng et al. independently infected rhesus monkeys with SARS-CoV-2 and then re-challenged these animals with the homologous virus. They found that animals indeed developed protective immune responses upon virus re-exposure at either 28 days [113] or 35 days [114] post-initial challenge.

NHP COVID-19 models have paved the way for the development of vaccines [115-119] and antiviral drugs that $[120,121]$ have undergone or are in Phase III clinical trials in several laboratories around the world.

\section{Other Miscellaneous Models}

The susceptibility of other animal hosts to SARS-CoV-2 have been investigated in order to identify animal models and hosts involved in the COVID-19 ecology. Although pigs (Sus scrofa domesticus) are susceptible to SARS-CoV infection, several attempts to infect pigs experimentally with SARS-CoV-2 have not been successful [95,122,123], even though some porcine cell lines support productive viral replication. Thus, pigs do not seem to play a role in SARS-CoV-2 dissemination and are not a suitable pre-clinical animal model to study SARS-CoV-2 pathogenesis or efficacy of respective vaccines or therapeutics. Bird species such as chickens and ducks are not susceptible to SARS-CoV-2, as defined by the lack of replication and seroconversion upon virus exposure [95,122].

Fruit bats (Rousettus aegyptiacus) experimentally infected with SARS-CoV-2 developed a transient infection, with rhinitis being a histopathological alteration detected without any clinical manifestation. SARS-CoV-2 RNA was detected in the trachea, lung, and lungassociated lymphatic tissue of infected animals and one out of three contact bats became infected, suggesting these animals may serve as a virus reservoir [122].

Raccoon dogs (Nyctereutes procyonoides) and minks (Neovison vison) are raised for fur production and have been shown to be susceptible to SARS-CoV-2 under experimental and natural conditions, respectively. Minks have been involved in the genesis of a new SARS-CoV-2 variant strain upon acquiring the infection from humans [58]. Infected minks on two farms in the Netherlands showed respiratory disease and increased mortality. In general, animals show signs of watery nasal discharge, although some minks could present severe breathing complications. Interstitial pneumonia was observed and viral RNA was detected in the nasal conchae, lung, throat and rectal swabs. In addition, viral RNA was also detected in the liver of one animal. Different genetic variants of SARS-CoV-2 derived from minks showed to be transmissible between animals from the same farm, but not between minks from other farms [124].

\section{Concluding Remarks}

Few months has passed since the discovery of SARS-CoV-2, nevertheless, great progress has already occurred in the development of in vitro and in vivo models capable of mimicking aspects of viral biology and COVID-19 pathology (Figure 1). These models have been applied in different areas, such as virus characterization and development of vaccines and antiviral therapies. Limitations of each model must be considered during experimental design. The most suitable models will vary according to the question to be answered and should provide reliable and translatable results for humans.

The use of in vitro models based on monolayer cultures of immortalized cell lines proves to be a faster and more straightforward approach for SARS-CoV-2 studies than primary cells. However, they often do not recapitulate the physiological conditions in vivo and primary cells and explants are an option in these cases. Most animal models developed so far are susceptible to SARS-CoV-2 infection and develop non-fatal diseases of various degrees of severity. Successful development of lethal SARS-CoV-2 models have been achieved by either expressing hACE-2 in mice or by serially passing the virus in conventional mice to produced mouse-adapted SARS-CoV-2. 


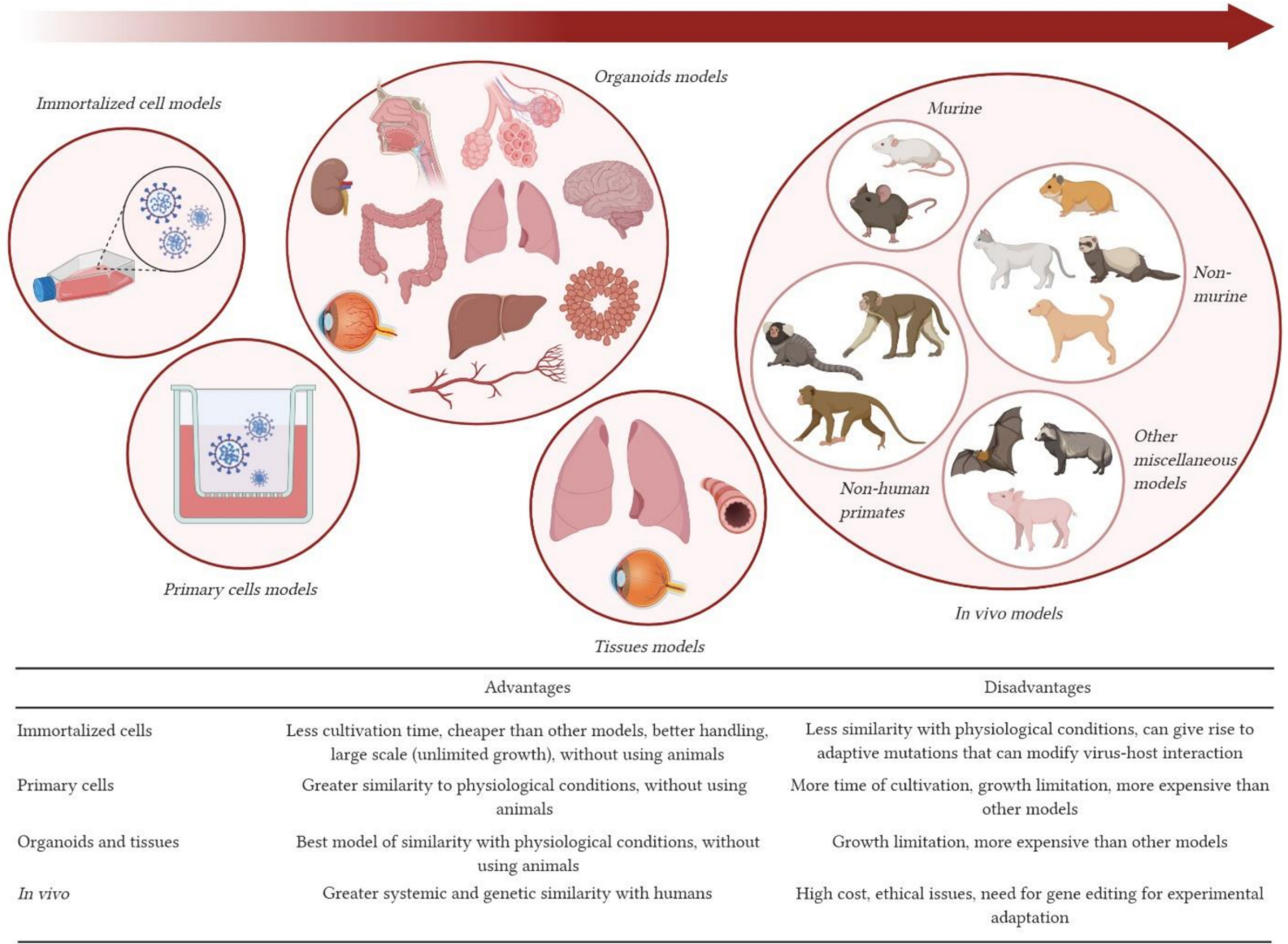

Figure 1. Models for severe acute respiratory syndrome coronavirus 2 (SARS-CoV-2) studies. In vitro, ex vivo and in vivo models previously reported were organized according to complexity level. Advantages and disadvantages of each model are summarized in the table below. Created with BioRender.com.

Each model has its own applicability in studies of the virus and the disease. Mice and hamsters are small animal models that are more easily available and are cheaper for housing, but translation of knowledge from rodent studies to the clinic can be challenging. Ferrets are excellent models for transmission, pathogenesis and countermeasure testing, but their availability in certain countries can be an issue and require special facilities for housing and breeding. Cats are natural hosts for SARS-CoV-2 and transmit the virus well, but do not display typical signs of disease. Non-human primates constitute the model most genetically close to humans, which is important for comparing host responses. However, the development of this model can be expensive and time-consuming. Despite the advances achieved so far, robust in vitro or in vivo models for SARS-CoV-2 infection still need to be determined. Characterization of new models will be important to foster SARS-CoV-2 research and help to control COVID-19 as the pandemic continues to take its toll.

Funding: The work in Pena's lab is funded by the Fiocruz Inova Program and Facepe (grant number APQ-0560-2.12/19). W.M.D. is recipient of a doctoral fellowship sponsored by CAPES-Brazil (Finance code 001). The funders had no role in study design, data collection and analysis, decision to publish, or preparation of the manuscript.

Institutional Review Board Statement: Not applicable.

Informed Consent Statement: Not applicable.

Data Availability Statement: Not applicable.

Conflicts of Interest: The authors declare no conflict of interest. 


\section{References}

1. Gao, Z.C. Efficient management of novel coronavirus pneumonia by efficient prevention and control in scientific manner. Zhonghua Jie He He Hu Xi Za Zhi 2020, 43, 163-166. [CrossRef] [PubMed]

2. Wu, F.; Zhao, S.; Yu, B.; Chen, Y.M.; Wang, W.; Song, Z.G.; Hu, Y.; Tao, Z.W.; Tian, J.H.; Pei, Y.Y.; et al. A new coronavirus associated with human respiratory disease in China. Nature 2020, 579, 265-269. [CrossRef]

3. Gorbalenya, A.E.; Baker, S.C.; Baric, R.S.; de Groot, R.J.; Drosten, C.; Gulyaeva, A.A.; Haagmans, B.L.; Lauber, C.; Leontovich, A.M.; Neuman, B.W.; et al. The species Severe acute respiratory syndrome-related coronavirus: Classifying 2019-nCoV and naming it SARS-CoV-2. Nat. Microbiol. 2020, 5, 536-544. [CrossRef]

4. Bin, D.; Haibo, Q.; Xi, Z.; Yishan, W.; Hanyujie, K.; Xuyan, L.; Feng, W.; Bing, S.; Tong, Z.H. Pharmacotherapeutics for the new coronavirus pneumonia. Chin. J. Tuberc. Respir. Dis. 2020, 43, 185-188. [CrossRef]

5. Zheng, J. SARS-coV-2: An emerging coronavirus that causes a global threat. Int. J. Biol. Sci. 2020, 16, 1678-1685. [CrossRef] [PubMed]

6. Hong, N.; Yu, W.; Xia, J.; Shen, Y.; Yap, M.; Han, W. Evaluation of ocular symptoms and tropism of SARS-CoV-2 in patients confirmed with COVID-19. Acta Ophthalmol. 2020, 1-7. [CrossRef]

7. Jin, X.; Lian, J.S.; Hu, J.H.; Gao, J.; Zheng, L.; Zhang, Y.M.; Hao, S.R.; Jia, H.Y.; Cai, H.; Zhang, X.L.; et al. Epidemiological, clinical and virological characteristics of 74 cases of coronavirus-infected disease 2019 (COVID-19) with gastrointestinal symptoms. Gut 2020, 1002-1009. [CrossRef]

8. Prasad, A.; Prasad, M. Single Virus Targeting Multiple Organs: What We Know and Where We Are Heading? Front. Med. 2020, 7 , 5-10. [CrossRef]

9. Xia, S.; Wu, M.; Chen, S.; Zhang, T.; Ye, L.; Liu, J.; Li, H. Long Term Culture of Human Kidney Proximal Tubule Epithelial Cells Maintains Lineage Functions and Serves as an Ex vivo Model for Coronavirus Associated Kidney Injury. Virol. Sin. 2020, 35, 1-10. [CrossRef]

10. Hui, K.P.Y.; Cheung, M.C.; Perera, R.A.P.M.; Ng, K.C.; Bui, C.H.T.; Ho, J.C.W.; Ng, M.M.T.; Kuok, D.I.T.; Shih, K.C.; Tsao, S.W.; et al. Tropism, replication competence, and innate immune responses of the coronavirus SARS-CoV-2 in human respiratory tract and conjunctiva: An analysis in ex-vivo and in-vitro cultures. Lancet Respir. Med. 2020, 2600, 1-9. [CrossRef]

11. Alexander, S.P.H.; Armstrong, J.F.; Davenport, A.P.; Davies, J.A.; Faccenda, E.; Harding, S.D.; Levi-Schaffer, F.; Maguire, J.J.; Pawson, A.J.; Southan, C.; et al. A rational roadmap for SARS-CoV-2/COVID-19 pharmacotherapeutic research and development: IUPHAR Review 29. Br. J. Pharmacol. 2020, 177, 4942-4966. [CrossRef]

12. Pena, L.J.; Guarines, K.M.; Duarte Silva, A.J.; Sales Leal, L.R.; Félix, D.M.; Silva, A.; De Oliveira, S.A.; Junqueira Ayres, C.F.; Silva JúNior, A.; De Freitas, A.C. In vitro and in vivo models for studying Zika virus biology. J. Gen. Virol. 2018, 99, 1529-1550. [CrossRef]

13. Ren, X.; Glende, J.; Al-Falah, M.; de Vries, V.; Schwegmann-Wessels, C.; Qu, X.; Tan, L.; Tschernig, T.; Deng, H.; Naim, H.Y.; et al. Analysis of ACE2 in polarized epithelial cells: Surface expression and function as receptor for severe acute respiratory syndrome-associated coronavirus. J. Gen. Virol. 2006, 87, 1691-1695. [CrossRef]

14. Hoffmann, M.; Kleine-Weber, H.; Schroeder, S.; Krüger, N.; Herrler, T.; Erichsen, S.; Schiergens, T.S.; Herrler, G.; Wu, N.H.; Nitsche, A.; et al. SARS-CoV-2 Cell Entry Depends on ACE2 and TMPRSS2 and Is Blocked by a Clinically Proven Protease Inhibitor. Cell 2020, 181, 271-280.e8. [CrossRef]

15. Zhou, P.; Yang, X.L.; Wang, X.G.; Hu, B.; Zhang, L.; Zhang, W.; Si, H.R.; Zhu, Y.; Li, B.; Huang, C.L.; et al. A pneumonia outbreak associated with a new coronavirus of probable bat origin. Nature 2020, 579, 270-273. [CrossRef]

16. Park, W.B.; Kwon, N.J.; Choi, S.J.; Kang, C.K.; Choe, P.G.; Kim, J.Y.; Yun, J.; Lee, G.W.; Seong, M.W.; Kim, N.J.; et al. Virus isolation from the first patient with SARS-CoV-2 in Korea. J. Korean Med. Sci. 2020, 35, 10-14. [CrossRef] [PubMed]

17. Harcourt, J.; Tamin, A.; Lu, X.; Kamili, S.; Sakthivel, S.K.; Murray, J.; Queen, K.; Tao, Y.; Paden, C.R.; Zhang, J.; et al. Severe acute respiratory syndrome coronavirus 2 from patient with coronavirus disease, United States. Emerg. Infect. Dis. 2020, 26, 1266-1273. [CrossRef] [PubMed]

18. Araujo, D.B.; Machado, R.R.G.; Amgarten, D.E.; Malta, F.d.M.; de Araujo, G.G.; Monteiro, C.O.; Candido, E.D.; Soares, C.P.; de Menezes, F.G.; Pires, A.C.C.; et al. SARS-CoV-2 isolation from the first reported patients in Brazil and establishment of a coordinated task network. Mem. Inst. Oswaldo Cruz 2020, 115, e200342. [CrossRef]

19. Milewska, A.; Kula-Pacurar, A.; Wadas, J.; Suder, A.; Szczepanski, A.; Dabrowska, A.; Owczarek, K.; Marcello, A.; Ochman, M.; Stacel, T.; et al. Replication of Severe Acute Respiratory Syndrome Coronavirus 2 in Human Respiratory Epithelium. J. Virol. 2020, 94, 1-7. [CrossRef] [PubMed]

20. Klimstra, W.B.; Tilston-Lunel, N.L.; Nambulli, S.; Boslett, J.; McMillen, C.M.; Gilliland, T.; Dunn, M.D.; Sun, C.; Wheeler, S.E.; Wells, A.; et al. SARS-CoV-2 growth, furin-cleavage-site adaptation and neutralization using serum from acutely infected hospitalized COVID-19 patients. J. Gen. Virol. 2020, 101, 1156-1169. [CrossRef]

21. Liu, Z.; Zheng, H.; Lin, H.; Li, M.; Yuan, R.; Peng, J.; Xiong, Q.; Sun, J.; Li, B.; Wu, J.; et al. Identification of common deletions in the spike protein of SARS-CoV-2. J. Virol. 2020, 1-9. [CrossRef]

22. Hoehl, S.; Rabenau, H.; Berger, A.; Kortenbusch, M.; Cinatl, J.; Bojkova, D.; Behrens, P.; Böddinghaus, B.; Götsch, U.; Naujoks, F.; et al. Evidence of SARS-CoV-2 infection in returning travelers from Wuhan, China. N. Engl. J. Med. 2020, 382, 1278-1280. [CrossRef] [PubMed] 
23. Bojkova, D.; Klann, K.; Koch, B.; Widera, M.; Krause, D.; Ciesek, S.; Cinatl, J.; Münch, C. Proteomics of SARS-CoV-2-infected host cells reveals therapy targets. Nature 2020. [CrossRef]

24. Daniloski, Z.; Jordan, T.X.; Wessels, H.H.; Hoagland, D.A.; Kasela, S.; Legut, M.; Maniatis, S.; Mimitou, E.P.; Lu, L.; Geller, E.; et al. Identification of Required Host Factors for SARS-CoV-2 Infection in Human Cells. Cell 2020, 92-105. [CrossRef] [PubMed]

25. Fan, H.H.; Wang, L.Q.; Liu, W.L.; An, X.P.; Liu, Z.D.; He, X.Q.; Song, L.H.; Tong, Y.G. Repurposing of clinically approved drugs for treatment of coronavirus disease 2019 in a 2019-novel coronavirus-related coronavirus model. Chin. Med. J. (Engl). 2020, 133, 1051-1056. [CrossRef]

26. Ma, C.; Sacco, M.D.; Hurst, B.; Townsend, J.A.; Hu, Y.; Szeto, T.; Zhang, X.; Tarbet, B.; Marty, M.T.; Chen, Y.; et al. Boceprevir, GC-376, and calpain inhibitors II, XII inhibit SARS-CoV-2 viral replication by targeting the viral main protease. Cell Res. 2020. [CrossRef] [PubMed]

27. Swaim, C.D.; Perng, Y.-C.; Zhao, X.; Canadeo, L.A.; Harastani, H.H.; Darling, T.L.; Boon, A.C.M.; Lenschow, D.J.; Huibregtse, J.M. 6-Thioguanine blocks SARS-CoV-2 replication by inhibition of PLpro protease activities. bioRxiv Prepr. Serv. Biol. 2020, 1-20. [CrossRef]

28. Pruijssers, A.J.; George, A.S.; Schäfer, A.; Leist, S.R.; Gralinksi, L.E.; Dinnon, K.H.; Yount, B.L.; Agostini, M.L.; Stevens, L.J.; Chappell, J.D.; et al. Remdesivir Inhibits SARS-CoV-2 in Human Lung Cells and Chimeric SARS-CoV Expressing the SARS-CoV-2 RNA Polymerase in Mice. Cell Rep. 2020, 32. [CrossRef]

29. Caly, L.; Druce, J.D.; Catton, M.G.; Jans, D.A.; Wagstaff, K.M. The FDA-approved drug ivermectin inhibits the replication of SARS-CoV-2 in vitro. Antiviral Res. 2020, 178, 3-6. [CrossRef]

30. Yao, X.; Ye, F.; Zhang, M.; Cui, C.; Huang, B.; Niu, P.; Liu, X.; Zhao, L.; Dong, E.; Song, C.; et al. In Vitro Antiviral Activity and Projection of Optimized Dosing Design of Hydroxychloroquine for the Treatment of Severe Acute Respiratory Syndrome Coronavirus 2 (SARS-CoV-2). Clin. Infect. Dis. 2020, 1-8. [CrossRef]

31. Kaur, H.; Shekhar, N.; Sharma, S.; Sarma, P.; Prakash, A.; Medhi, B. Ivermectin as a potential drug for treatment of COVID-19: An in-sync review with clinical and computational attributes. Pharmacol. Reports 2021. [CrossRef]

32. Sands, K.; Wenzel, R.; McLean, L.; Korwek, K.; Roach, J.; Miller, K.; Poland, R.E.; Burgess, L.H.; Jackson, E.; Perlin, J.B. No clinical benefit in mortality associated with hydroxychloroquine treatment in patients with COVID-19. Int. J. Infect. Dis. 2021, 104, 34-40. [CrossRef]

33. Banach, B.S.; Orenstein, J.M.; Fox, L.M.; Randell, S.H.; Rowley, A.H.; Baker, S.C. Human airway epithelial cell culture to identify new respiratory viruses: Coronavirus NL63 as a model. J. Virol. Methods 2009, 156, 19-26. [CrossRef]

34. Jonsdottir, H.R.; Dijkman, R. Coronaviruses and the human airway: A universal system for virus-host interaction studies Coronaviruses: Emerging and re-emerging pathogens in humans and animals Susanna Lau Emerging viruses. Virol. J. 2016, 13, 1-9. [CrossRef] [PubMed]

35. Liu, X.; Wu, Y.; Rong, L. Conditionally Reprogrammed Human Normal Airway Epithelial Cells at ALI: A Physiological Model for Emerging Viruses. Virol. Sin. 2020, 12250, 1-10. [CrossRef]

36. Hou, Y.J.; Okuda, K.; Edwards, C.E.; Martinez, D.R.; Asakura, T.; Dinnon, K.H.; Kato, T.; Lee, R.E.; Yount, B.L.; Mascenik, T.M.; et al. SARS-CoV-2 Reverse Genetics Reveals a Variable Infection Gradient in the Respiratory Tract. Cell 2020, 1-18. [CrossRef]

37. Shang, J.; Wan, Y.; Luo, C.; Ye, G.; Geng, Q.; Auerbach, A.; Li, F. Cell entry mechanisms of SARS-CoV-2. Proc. Natl. Acad. Sci. USA 2020, 117. [CrossRef]

38. Abo, K.M.; Ma, L.; Matte, T.; Huang, J.; Alysandratos, K.D.; Werder, R.B.; Mithal, A.; Beermann, M.L.; Lindstrom-Vautrin, J.; Mostoslavsky, G.; et al. Human iPSC-derived alveolar and airway epithelial cells can be cultured at air-liquid interface and express SARS-CoV-2 host factors. bioRxiv 2020. [CrossRef]

39. Sungnak, W.; Huang, N.; Bécavin, C.; Berg, M.; Queen, R.; Litvinukova, M.; Talavera-López, C.; Maatz, H.; Reichart, D.; Sampaziotis, F.; et al. SARS-CoV-2 entry factors are highly expressed in nasal epithelial cells together with innate immune genes. Nat. Med. 2020, 26, 681-687. [CrossRef] [PubMed]

40. Stelzig, K.E.; Canepa-Escaro, F.; Schiliro, M.; Berdnikovs, S.; Prakash, Y.S.; Chiarella, S.E. Estrogen regulates the expression of SARS-CoV-2 receptor ACE2 in differentiated airway epithelial cells. Am. J. Physiol. Lung Cell. Mol. Physiol. 2020, 318, L1280-L1281. [CrossRef] [PubMed]

41. Blanco-Melo, D.; Nilsson-Payant, B.E.; Liu, W.C.; Uhl, S.; Hoagland, D.; Møller, R.; Jordan, T.X.; Oishi, K.; Panis, M.; Sachs, D.; et al. Imbalanced Host Response to SARS-CoV-2 Drives Development of COVID-19. Cell 2020, 181, 1036-1045.e9. [CrossRef]

42. Sheahan, T.P.; Sims, A.C.; Zhou, S.; Graham, R.L.; Pruijssers, A.J.; Agostini, M.L.; Leist, S.R.; Schäfer, A.; Dinnon, K.H.; Stevens, L.J.; et al. An orally bioavailable broad-spectrum antiviral inhibits SARS-CoV-2 in human airway epithelial cell cultures and multiple coronaviruses in mice. Sci. Transl. Med. 2020, 12. [CrossRef]

43. Clevers, H. COVID-19: Organoids go viral. Nat. Rev. Mol. Cell Biol. 2020, 21, 355-356. [CrossRef]

44. Qi, F.; Qian, S.; Zhang, S.; Zhang, Z. Single cell RNA sequencing of 13 human tissues identify cell types and receptors of human coronaviruses. Biochem. Biophys. Res. Commun. 2020, 526, 135-140. [CrossRef]

45. Singh, M.; Bansal, V.; Feschotte, C. A Single-Cell RNA Expression Map of Human Coronavirus Entry Factors. Cell Rep. 2020, 32. [CrossRef]

46. Chu, H.; Chan, J.F.W.; Wang, Y.; Yuen, T.T.T.; Chai, Y.; Hou, Y.; Shuai, H.; Yang, D.; Hu, B.; Huang, X.; et al. Comparative replication and immune activation profiles of SARS-CoV-2 and SARS-CoV in human lungs: An ex vivo study with implications for the pathogenesis of COVID-19. Clin. Infect. Dis. 2020, 1-10. [CrossRef] 
47. Yang, L.; Han, Y.; Nilsson-Payant, B.E.; Gupta, V.; Wang, P.; Duan, X.; Tang, X.; Zhu, J.; Zhao, Z.; Jaffré, F.; et al. A Human Pluripotent Stem Cell-based Platform to Study SARS-CoV-2 Tropism and Model Virus Infection in Human Cells and Organoids. Cell Stem Cell 2020, 27, 125-136.e7. [CrossRef] [PubMed]

48. Han, Y.; Duan, X.; Yang, L.; Nilsson-Payant, B.E.; Wang, P.; Duan, F.; Tang, X.; Yaron, T.M.; Zhang, T.; Uhl, S.; et al. Identification of SARS-CoV-2 Inhibitors using Lung and Colonic Organoids. Nature 2020, 589, 270-275. [CrossRef] [PubMed]

49. Matschke, J.; Lütgehetmann, M.; Hagel, C.; Sperhake, J.P.; Schröder, A.S.; Edler, C.; Mushumba, H.; Fitzek, A.; Allweiss, L.; Dandri, M.; et al. Neuropathology of patients with COVID-19 in Germany: A post-mortem case series. Lancet Neurol. 2020, 19, 919-929. [CrossRef]

50. Ramani, A.; Müller, L.; Ostermann, P.N.; Gabriel, E.; Abida-Islam, P.; Müller-Schiffmann, A.; Mariappan, A.; Goureau, O.; Gruell, H.; Walker, A.; et al. SARS -CoV-2 targets neurons of 3D human brain organoids. EMBO J. 2020, 39, 1-14. [CrossRef]

51. Zhang, B.Z.; Chu, H.; Han, S.; Shuai, H.; Deng, J.; Hu, Y.F.; Gong, H.R.; Lee, A.C.Y.; Zou, Z.; Yau, T.; et al. SARS-CoV-2 infects human neural progenitor cells and brain organoids. Cell Res. 2020, 30, 928-931. [CrossRef]

52. Leonardi, A.; Rosani, U.; Brun, P. Ocular Surface Expression of SARS-CoV-2 Receptors. Ocul. Immunol. Inflamm. 2020, 28 , 735-738. [CrossRef]

53. Wu, P.; Duan, F.; Luo, C.; Liu, Q.; Qu, X.; Liang, L.; Wu, K. Characteristics of Ocular Findings of Patients with Coronavirus Disease 2019 (COVID-19) in Hubei Province, China. JAMA Ophthalmol. 2020, 138, 575-578. [CrossRef]

54. Seah, I.Y.J.; Anderson, D.E.; Kang, A.E.Z.; Wang, L.; Rao, P.; Young, B.E.; Lye, D.C.; Agrawal, R. Assessing Viral Shedding and Infectivity of Tears in Coronavirus Disease 2019 (COVID-19) Patients. Ophthalmology 2020, 127, 977-979. [CrossRef] [PubMed]

55. Makovoz, B.; Moeller, R.; Zebitz Eriksen, A.; tenOever, B.R.; Blenkinsop, T.A. SARS-CoV-2 Infection of Ocular Cells from Human Adult Donor Eyes and hESC-Derived Eye Organoids. Ssrn 2020, 3650574. [CrossRef]

56. Monteil, V.; Kwon, H.; Prado, P.; Hagelkrüys, A.; Wimmer, R.A.; Stahl, M.; Leopoldi, A.; Garreta, E.; Hurtado del Pozo, C.; Prosper F.; et al. Inhibition of SARS-CoV-2 Infections in Engineered Human Tissues Using Clinical-Grade Soluble Human ACE2. Cell 2020, 181, 905-913.e7. [CrossRef] [PubMed]

57. Yuan, L.; Tang, Q.; Cheng, T.; Xia, N. Animal models for emerging coronavirus: Progress and new insights. Emerg. Microbes Infect. 2020, 9, 949-961. [CrossRef]

58. Muñoz-Fontela, C.; Dowling, W.E.; Funnell, S.G.P.; Gsell, P.S.; Riveros-Balta, A.X.; Albrecht, R.A.; Andersen, H.; Baric, R.S.; Carroll, M.W.; Cavaleri, M.; et al. Animal models for COVID-19. Nature 2020, 586, 509-515. [CrossRef] [PubMed]

59. Wan, Y.; Shang, J.; Graham, R.; Baric, R.S.; Li, F. Receptor Recognition by the Novel Coronavirus from Wuhan: An Analysis Based on Decade-Long Structural Studies of SARS Coronavirus. J. Virol. 2020, 94, 1-9. [CrossRef] [PubMed]

60. Frieman, M.; Yount, B.; Agnihothram, S.; Page, C.; Donaldson, E.; Roberts, A.; Vogel, L.; Woodruff, B.; Scorpio, D.; Subbarao, K.; et al. Molecular Determinants of Severe Acute Respiratory Syndrome Coronavirus Pathogenesis and Virulence in Young and Aged Mouse Models of Human Disease. J. Virol. 2012, 86, 884-897. [CrossRef]

61. Menachery, V.D.; Yount, B.L.; Sims, A.C.; Debbink, K.; Agnihothram, S.S.; Gralinski, L.E.; Graham, R.L.; Scobey, T.; Plante, J.A.; Royal, S.R.; et al. SARS-like WIV1-CoV poised for human emergence. Proc. Natl. Acad. Sci. USA 2016, 113, 3048-3053. [CrossRef]

62. Roberts, A.; Deming, D.; Paddock, C.D.; Cheng, A.; Yount, B.; Vogel, L.; Herman, B.D.; Sheahan, T.; Heise, M.; Genrich, G.L.; et al. A mouse-adapted SARS-coronavirus causes disease and mortality in BALB/c mice. PLoS Pathog. 2007, 3, 0023-0037. [CrossRef]

63. Tseng, C.-T.K.; Huang, C.; Newman, P.; Wang, N.; Narayanan, K.; Watts, D.M.; Makino, S.; Packard, M.M.; Zaki, S.R.; Chan, T.; et al. Severe Acute Respiratory Syndrome Coronavirus Infection of Mice Transgenic for the Human Angiotensin-Converting Enzyme 2 Virus Receptor. J. Virol. 2007, 81, 1162-1173. [CrossRef]

64. Yang, X.H.; Deng, W.; Tong, Z.; Liu, Y.X.; Zhang, L.F.; Zhu, H.; Gao, H.; Huang, L.; Liu, Y.I.; Ma, C.M.; et al. Mice transgenic for human angiotensin-converting enzyme 2 provide a model for SARS coronavirus infection. Comp. Med. 2007, 57, 450-459. [PubMed]

65. Sun, S.H.; Chen, Q.; Gu, H.J.; Yang, G.; Wang, Y.X.; Huang, X.Y.; Liu, S.S.; Zhang, N.N.; Li, X.F.; Xiong, R.; et al. A Mouse Model of SARS-CoV-2 Infection and Pathogenesis. Cell Host Microbe 2020, 1-10. [CrossRef]

66. Ostrowski, L.E.; Hutchins, J.R.; Zakel, K.; O’Neal, W.K. Targeting expression of a transgene to the airway surface epithelium using a ciliated cell-specific promoter. Mol. Ther. 2003, 8, 637-645. [CrossRef]

67. Jiang, R.D.; Liu, M.Q.; Chen, Y.; Shan, C.; Zhou, Y.W.; Shen, X.R.; Li, Q.; Zhang, L.; Zhu, Y.; Si, H.R.; et al. Pathogenesis of SARS-CoV-2 in Transgenic Mice Expressing Human Angiotensin-Converting Enzyme 2. Cell 2020, 1-9. [CrossRef]

68. Bao, L.; Deng, W.; Huang, B.; Gao, H.; Liu, J.; Ren, L.; Wei, Q.; Yu, P.; Xu, Y.; Qi, F.; et al. The pathogenicity of SARS-CoV-2 in hACE2 transgenic mice. Nature 2020. [CrossRef]

69. Shulla, A.; Heald-Sargent, T.; Subramanya, G.; Zhao, J.; Perlman, S.; Gallagher, T. A Transmembrane Serine Protease Is Linked to the Severe Acute Respiratory Syndrome Coronavirus Receptor and Activates Virus Entry. J. Virol. 2011, 85, 873-882. [CrossRef]

70. Soldatov, V.O.; Kubekina, M.V.; Silaeva, Y.Y.; Bruter, A.V.; Deykin, A.V. On the way from SARS-CoV-sensitive mice to murine COVID-19 model. Res. Results Pharmacol. 2020, 6, 1-7. [CrossRef]

71. Dinnon, K.H.; Leist, S.R.; Schäfer, A.; Edwards, C.E.; Martinez, D.R.; Montgomery, S.A.; West, A.; Yount, B.L.; Hou, Y.J.; Adams, L.E.; et al. A mouse-adapted SARS-CoV-2 model for the evaluation of COVID-19 medical countermeasures. bioRxiv 2020. [CrossRef] 
72. Dinnon, K.H.; Leist, S.R.; Schäfer, A.; Edwards, C.E.; Martinez, D.R.; Montgomery, S.A.; West, A.; Yount, B.L.; Hou, Y.J.; Adams, L.E.; et al. A mouse-adapted model of SARS-CoV-2 to test COVID-19 countermeasures. Nature 2020, 586, 560-566. [CrossRef] [PubMed]

73. Hassan, A.O.; Case, J.B.; Winkler, E.S.; Thackray, L.B.; Kafai, N.M.; Bailey, A.L.; McCune, B.T.; Fox, J.M.; Chen, R.E.; Alsoussi, W.B.; et al. A SARS-CoV-2 Infection Model in Mice Demonstrates Protection by Neutralizing Antibodies. Cell 2020, 182, 744-753.e4. [CrossRef]

74. Israelow, B.; Song, E.; Mao, T.; Lu, P.; Meir, A.; Liu, F.; Alfajaro, M.M.; Wei, J.; Dong, H.; Homer, R.J.; et al. Mouse model of SARS-CoV-2 reveals inflammatory role of type i interferon signaling. J. Exp. Med. 2020, 217. [CrossRef]

75. Zhang, Y.N.; Li, X.D.; Zhang, Z.R.; Zhang, H.Q.; Li, N.; Liu, J.; Li, J.Q.; Zhang, H.J.; Wang, Z.J.; Shen, S.; et al. A mouse model for SARS-CoV-2 infection by exogenous delivery of hACE2 using alphavirus replicon particles. Cell Res. 2020, 30, 1046-1048. [CrossRef]

76. Rathnasinghe, R.; Strohmeier, S.; Amanat, F.; Gillespie, V.L.; Krammer, F.; García-Sastre, A.; Coughlan, L.; Schotsaert, M.; Uccellini, M. Comparison of Transgenic and Adenovirus hACE2 Mouse Models for SARS-CoV-2 Infection. Emerg. Microbes Infect. 2020, 1-19. [CrossRef]

77. Gu, H.; Chen, Q.; Yang, G.; He, L.; Fan, H.; Deng, Y.Q.; Wang, Y.; Teng, Y.; Zhao, Z.; Cui, Y.; et al. Adaptation of SARS-CoV-2 in BALB/c mice for testing vaccine efficacy. Science 2020, 369, 1603-1607. [CrossRef]

78. Damas, J.; Hughes, G.M.; Keough, K.C.; Painter, C.A.; Persky, N.S.; Corbo, M.; Hiller, M.; Koepfli, K.P.; Pfenning, A.R.; Zhao, H.; et al. Broad host range of SARS-CoV-2 predicted by comparative and structural analysis of ACE2 in vertebrates. Proc. Natl. Acad. Sci. USA 2020, 117, 22311-22322. [CrossRef] [PubMed]

79. Chan, J.F.; Zhang, A.J.; Yuan, S.; Kwok-, V. Simulation of the clinical and pathological manifestations of Coronavirus Disease 2019 (COVID-19) in golden Syrian hamster model: Implications for disease pathogenesis and transmissibility. Clin Infect Dis. 2019, 1-50. [CrossRef]

80. Sia, S.F.; Yan, L.M.; Chin, A.W.H.; Fung, K.; Choy, K.T.; Wong, A.Y.L.; Kaewpreedee, P.; Perera, R.A.P.M.; Poon, L.L.M.; Nicholls, J.M.; et al. Pathogenesis and transmission of SARS-CoV-2 in golden hamsters. Nature 2020. [CrossRef] [PubMed]

81. Imai, M.; Iwatsuki-Horimoto, K.; Hatta, M.; Loeber, S.; Halfmann, P.J.; Nakajima, N.; Watanabe, T.; Ujie, M.; Takahashi, K.; Ito, M.; et al. Syrian hamsters as a small animal model for SARS-CoV-2 infection and countermeasure development. Proc. Natl. Acad. Sci. USA 2020, 117, 16587-16595. [CrossRef] [PubMed]

82. Boudewijns, R.; Thibaut, H.J.; Kaptein, S.J.F.; Li, R.; Vergote, V.; Seldeslachts, L.; Van Weyenbergh, J.; De Keyzer, C.; Bervoets, L.; Sharma, S.; et al. STAT2 signaling restricts viral dissemination but drives severe pneumonia in SARS-CoV-2 infected hamsters. Nat. Commun. 2020, 11, 1-10. [CrossRef] [PubMed]

83. Osterrieder, N.; Bertzbach, L.D.; Dietert, K.; Abdelgawad, A.; Vladimirova, D.; Kunec, D.; Hoffmann, D.; Beer, M.; Gruber, A.D.; Trimpert, J. Age-dependent progression of SARS-CoV-2 infection in Syrian hamsters. Viruses 2020, 12, 779. [CrossRef]

84. Chan, J.F.-W.; Yuan, S.; Zhang, A.J.; Poon, V.K.-M.; Chan, C.C.-S.; Lee, A.C.-Y.; Fan, Z.; Li, C.; Liang, R.; Cao, J.; et al. Surgical Mask Partition Reduces the Risk of Noncontact Transmission in a Golden Syrian Hamster Model for Coronavirus Disease 2019 (COVID-19). Clin. Infect. Dis. 2020, 2019, 1-11. [CrossRef] [PubMed]

85. Mohandas, S.; Shete, A.; Abraham, P.; Mohan, K. Immunogenicity and protective e cacy of BBV152: A whole virion inactivated SARS CoV-2 vaccine in the Syrian hamster model. Res. Sq. 2020, 1-25.

86. Vitner, E.B.; Israeli, O.; Milrot, E.; Stein, D.; Cohen-gihon, I.; Lazar, S.; Gutman, H.; Lupu, E.; David, E.B.; Sittner, A.; et al. A single dose of recombinant VSV- $\Delta$ G-spike vaccine provides protection against SARS-CoV-2 challenge Yfat. Nat. Commun. 2020, 11, 6402.

87. Tostanoski, L.H.; Wegmann, F.; Martinot, A.J.; Loos, C.; McMahan, K.; Mercado, N.B.; Yu, J.; Chan, C.N.; Bondoc, S.; Starke, C.E.; et al. Ad26 vaccine protects against SARS-CoV-2 severe clinical disease in hamsters. Nat. Med. 2020. [CrossRef] [PubMed]

88. Kaptein, S.J.F.; Jacobs, S.; Langendries, L.; Seldeslachts, L.; ter Horst, S.; Liesenborghs, L.; Hens, B.; Vergote, V.; Heylen, E.; Barthelemy, K.; et al. Favipiravir at high doses has potent antiviral activity in SARS-CoV-2-infected hamsters, whereas hydroxychloroquine lacks activity. Proc. Natl. Acad. Sci. USA 2020, 117, 26955-26965. [CrossRef]

89. Yuan, S.; Wang, R.; Chan, J.F.W.; Zhang, A.J.; Cheng, T.; Chik, K.K.H.; Ye, Z.W.; Wang, S.; Lee, A.C.Y.; Jin, L.; et al. Metallodrug ranitidine bismuth citrate suppresses SARS-CoV-2 replication and relieves virus-associated pneumonia in Syrian hamsters. Nat. Microbiol. 2020, 5, 1439-1448. [CrossRef]

90. Yuan, S.; Yin, X.; Meng, X.; Chan, J.; Ye, Z.-W.; Riva, L.; Pache, L.; Chan, C.C.-Y.; Lai, P.-M.; Chan, C.; et al. Clofazimine is a broad-spectrum coronavirus inhibitor that antagonizes SARS-CoV-2 replication in primary human cell culture and hamsters. Res. Sq. 2020, 1-26. [CrossRef]

91. Sun, X.; Meyerholz, D.K.; Engelhardt, J.F.; Sun, X.; Sui, H.; Fisher, J.T.; Yan, Z.; Liu, X.; Cho, H.; Joo, N.S.; et al. Disease phenotype of a ferret CFTR-knockout model of cystic fibrosis. J. Clin. Investig. 2010, 120, 3149-3160. [CrossRef]

92. Guan, W.; Ni, Z.; Hu, Y.; Liang, W.; Ou, C.; He, J.; Liu, L.; Shan, H.; Lei, C.; Hui, D.S.C.; et al. Clinical characteristics of coronavirus disease 2019 in China. N. Engl. J. Med. 2020, 382, 1708-1720. [CrossRef] [PubMed]

93. Park, S.J.; Yu, K.M.; Kim, Y.I.; Kim, S.M.; Kim, E.H.; Kim, S.G.; Kim, E.J.; Casel, M.A.B.; Rollon, R.; Jang, S.G.; et al. Antiviral efficacies of FDA-approved drugs against SARS-COV-2 infection in ferrets. MBio 2020, 11, 1-10. [CrossRef]

94. Wu, S.; Zhong, G.; Zhang, J.; Shuai, L.; Zhang, Z.; Wen, Z.; Wang, B.; Zhao, Z.; Song, X.; Chen, Y.; et al. A single dose of an adenovirus-vectored vaccine provides protection against SARS-CoV-2 challenge. Nat. Commun. 2020, 11. [CrossRef] 
95. Shi, J.; Wen, Z.; Zhong, G.; Yang, H.; Wang, C.; Huang, B.; Liu, R.; He, X.; Shuai, L.; Sun, Z.; et al. Susceptibility of ferrets, cats, dogs, and other domesticated animals to SARS-coronavirus 2. Science 2020, 368, 1016-1020. [CrossRef]

96. Ryan, K.A.; Bewley, K.R.; Fotheringham, S.A.; Brown, P.; Hall, Y.; Marriott, A.C.; Tree, J.A.; Allen, L.; Aram, M.J.; Brunt, E.; et al. Dose-dependent response to infection with SARS-CoV-2 in the ferret model: Evidence of protection to re-challenge. bioRxiv 2020, 2. [CrossRef]

97. Richard, M.; Kok, A.; de Meulder, D.; Bestebroer, T.M.; Lamers, M.M.; Okba, N.M.A.; van Vlissingen, M.F.; Rockx, B.; Haagmans, B.L.; Marion, P.G.; et al. SARS-CoV-2 is transmitted via contact and via the air between ferrets. Nat. Commun. 2020, $11,3496$. [CrossRef] [PubMed]

98. Kim, Y.I.; Kim, S.G.; Kim, S.M.; Kim, E.H.; Park, S.J.; Yu, K.M.; Chang, J.H.; Kim, E.J.; Lee, S.; Casel, M.A.B.; et al. Infection and Rapid Transmission of SARS-CoV-2 in Ferrets. Cell Host Microbe 2020, 27, 704-709.e2. [CrossRef] [PubMed]

99. Mathavarajah, S.; Dellaire, G. Lions, tigers and kittens too: ACE2 and susceptibility to COVID-19. Evol. Med. Public Heal. 2020, 2020, 109-113. [CrossRef] [PubMed]

100. Sit, T.H.C.; Brackman, C.J.; Ip, S.M.; Tam, K.W.S.; Law, P.Y.T.; To, E.M.W.; Yu, V.Y.T.; Sims, L.D.; Tsang, D.N.C.; Chu, D.K.W.; et al. Infection of dogs with SARS-CoV-2. Nature 2020. [CrossRef]

101. Bosco-Lauth, A.M.; Hartwig, A.E.; Porter, S.M.; Gordy, P.W.; Nehring, M.; Byas, A.D.; Vandewoude, S.; Ragan, I.K.; Maison, R.M.; Bowen, R.A. Pathogenesis, transmission and response to re-exposure of SARS-CoV-2 in domestic cats. BioRxiv 2020, 21, 1-9. [CrossRef]

102. Bosco-Lauth, A.M.; Hartwig, A.E.; Porter, S.M.; Gordy, P.W.; Nehring, M.; Byas, A.D.; VandeWoude, S.; Ragan, I.K.; Maison, R.M.; Bowen, R.A. Experimental infection of domestic dogs and cats with SARS-CoV-2: Pathogenesis, transmission, and response to reexposure in cats. Proc. Natl. Acad. Sci. USA 2020, 117, 26382-26388. [CrossRef] [PubMed]

103. Fritz, M.; Rosolen, B.; Krafft, E.; Becquart, P.; Elguero, E.; Vratskikh, O.; Denolly, S.; Boson, B.; Vanhomwegen, J. High prevalence of SARS-CoV-2 antibodies in pets from COVID-19+ households. One Health 2020, 11, 1-11. [CrossRef] [PubMed]

104. Zhang, Q.; Zhang, H.; Huang, K.; Yang, Y.; Hui, X.; Gao, J.; He, X.; Li, C.; Gong, W.; Zhang, Y.; et al. SARS-CoV-2 neutralizing serum antibodies in cats: A serological investigation. bioRxiv 2020. [CrossRef]

105. Halfmann, P.J.; Hatta, M.; Chiba, S.; Maemura, T.; Fan, S.; Takeda, M.; Kinoshita, N.; Hattori, S.; Sakai-Tagawa, Y.; IwatsukiHorimoto, K.; et al. Transmission of SARS-CoV-2 in Domestic Cats. N. Engl. J. Med. 2020. [CrossRef]

106. Rockx, B.; Kuiken, T.; Herfst, S.; Bestebroer, T.; Lamers, M.M.; Oude Munnink, B.B.; de Meulder, D.; van Amerongen, G.; van den Brand, J.; Okba, N.M.A.; et al. Comparative pathogenesis of COVID-19, MERS, and SARS in a nonhuman primate model. Science 2020, 368, 1012-1015. [CrossRef] [PubMed]

107. Munster, V.J.; Feldmann, F.; Williamson, B.N.; van Doremalen, N.; Pérez-Pérez, L.; Schulz, J.; Meade-White, K.; Okumura, A.; Callison, J.; Brumbaugh, B.; et al. Respiratory disease in rhesus macaques inoculated with SARS-CoV-2. Nature 2020. [CrossRef]

108. Lu, S.; Zhao, Y.; Yu, W.; Yang, Y.; Gao, J.; Wang, J.; Kuang, D.; Yang, M.; Yang, J.; Ma, C.; et al. Comparison of nonhuman primates identified the suitable model for COVID-19. Signal Transduct. Target. Ther. 2020, 5. [CrossRef]

109. Hartman, A.L.; Nambulli, S.; McMillen, C.M.; White, A.G.; Tilston-Lunel, N.L.; Albe, J.R.; Cottle, E.; Dunn, M.D.; James Frye, L.; Gilliland, T.H.; et al. SARS-CoV-2 infection of African green monkeys results in mild respiratory disease discernible by PET/CT imaging and shedding of infectious virus from both respiratory and gastrointestinal tracts. PLoS Pathog. 2020, 16, 1-24. [CrossRef]

110. Curtis, M.J.; Alexander, S.; Cirino, G.; Docherty, J.R.; George, C.H.; Giembycz, M.A.; Hoyer, D.; Insel, P.A.; Izzo, A.A.; Ji, Y.; et al Experimental design and analysis and their reporting II: Updated and simplified guidance for authors and peer reviewers. Br. J. Pharmacol. 2018, 175, 987-993. [CrossRef]

111. Deng, W.; Bao, L.; Gao, H.; Xiang, Z.; Qu, Y.; Song, Z.; Gong, S.; Liu, J.; Liu, J.; Yu, P.; et al. Ocular conjunctival inoculation of SARS-CoV-2 can cause mild COVID-19 in rhesus macaques. Nat. Commun. 2020, 11, 1-7. [CrossRef]

112. Yu, P.; Qi, F.; Xu, Y.; Li, F.; Liu, P.; Liu, J.; Bao, L.; Deng, W.; Gao, H.; Xiang, Z.; et al. Age-related rhesus macaque models of COVID-19. Anim. Model. Exp. Med. 2020, 3, 93-97. [CrossRef] [PubMed]

113. Deng, W.; Bao, L.; Liu, J.; Xiao, C.; Liu, J.; Xue, J.; Lv, Q.; Qi, F.; Gao, H.; Yu, P.; et al. Primary exposure to SARS-CoV-2 protects against reinfection in rhesus macaques. Science 2020, 369, 818-823. [CrossRef]

114. Chandrashekar, A.; Liu, J.; Martino, A.J.; McMahan, K.; Mercad, N.B.; Peter, L.; Tostanosk, L.H.; Yu, J.; Maliga, Z.; Nekorchuk, M.; et al. SARS-CoV-2 infection protects against rechallenge in rhesus macaques. Science 2020, 369, 812-817. [CrossRef]

115. Yu, J.; Tostanosk, L.H.; Peter, L.; Mercad, N.B.; McMahan, K.; Mahrokhia, S.H.; Nkolol, J.P.; Liu, J.; Li, Z.; Chandrashekar, A.; et al. DNA vaccine protection against SARS-CoV-2 in rhesus macaques. Science 2020, 369, 806-811. [CrossRef]

116. Wang, H.; Zhang, Y.; Huang, B.; Deng, W.; Quan, Y.; Wang, W.; Xu, W.; Zhao, Y.; Li, N.; Zhang, J.; et al. Development of an Inactivated Vaccine Candidate, BBIBP-CorV, with Potent Protection against SARS-CoV-2. Cell 2020, 182, 713-721.e9. [CrossRef] [PubMed]

117. Mercado, N.B.; Zahn, R.; Wegmann, F.; Loos, C.; Chandrashekar, A.; Yu, J.; Liu, J.; Peter, L.; McMahan, K.; Tostanoski, L.H.; et al. Single-shot Ad26 vaccine protects against SARS-CoV-2 in rhesus macaques. Nature 2020, 586, 583-588. [CrossRef] [PubMed]

118. Doremalen, N.; Lambe, T.; Spencer, A.; Belij-Rammerstorfer, S.; Purushotham, J.N.; Port, J.R.; Avanzato, V.A.; Bushmaker, T.; Flaxman, A.; Ulaszewska, M.; et al. ChAdOx1 nCoV-19 vaccine prevents SARS-CoV-2 pneumonia in rhesus macaques. Nature 2020, 586, 578-582. [CrossRef] 
119. Corbett, K.S.; Flynn, B.; Foulds, K.E.; Francica, J.R.; Boyoglu-Barnum, S.; Werner, A.P.; Flach, B.; O'Connell, S.; Bock, K.W.; Minai, M.; et al. Evaluation of the mRNA-1273 Vaccine against SARS-CoV-2 in Nonhuman Primates. N. Engl. J. Med. 2020, 383, 1544-1555. [CrossRef] [PubMed]

120. Maisonnasse, P.; Guedj, J.; Contreras, V.; Behillil, S.; Solas, C.; Marlin, R.; Naninck, T.; Pizzorno, A.; Lemaitre, J.; Gonçalves, A.; et al. Hydroxychloroquine use against SARS-CoV-2 infection in non-human primates. Nature 2020, 585, 584-587. [CrossRef]

121. Williamson, B.N.; Feldmann, F.; Schwarz, B.; Meade-White, K.; Porter, D.P.; Schulz, J.; van Doremalen, N.; Leighton, I.; Yinda C.K.; Pérez-Pérez, L.; et al. Clinical benefit of remdesivir in rhesus macaques infected with SARS-CoV-2. Nature 2020. [CrossRef]

122. Schlottau, K.; Rissmann, M.; Graaf, A.; Schön, J.; Sehl, J.; Wylezich, C.; Höper, D.; Mettenleiter, T.C.; Balkema-Buschmann, A.; Harder, T.; et al. SARS-CoV-2 in fruit bats, ferrets, pigs, and chickens: An experimental transmission study. Lancet Microbe 2020, 1 , e218-e225. [CrossRef]

123. Meekins, D.A.; Morozov, I.; Trujillo, J.D.; Gaudreault, N.N.; Bold, D.; Carossino, M.; Artiaga, B.L.; Indran, S.V.; Kwon, T.; Balaraman, V.; et al. Susceptibility of swine cells and domestic pigs to SARS-CoV-2. Emerg. Microbes Infect. 2020, 9, $2278-2288$. [CrossRef] [PubMed]

124. Oreshkova, N.; Molenaar, R.J.; Vreman, S.; Harders, F.; Oude Munnink, B.B.; Van Der Honing, R.W.H.; Gerhards, N.; Tolsma, P.; Bouwstra, R.; Sikkema, R.S.; et al. SARS-CoV-2 infection in farmed minks, the Netherlands, April and May 2020. Eurosurveillance 2020, 25, 1-7. [CrossRef] [PubMed] 